University of Wollongong

Research Online

Faculty of Engineering and Information

Faculty of Engineering and Information

Sciences - Papers: Part B

Sciences

2018

Integrated life cycle cost method for sustainable structural design by

focusing on a benchmark office building in Australia

Mehdi Robati

University of Wollongong, University of New South Wales, mrobati@uow.edu.au

Timothy J. McCarthy

University of Wollongong, timmc@uow.edu.au

Georgios Kokogiannakis

University of Wollongong, gkg@uow.edu.au

Follow this and additional works at: https://ro.uow.edu.au/eispapers1

Part of the Engineering Commons, and the Science and Technology Studies Commons

Research Online is the open access institutional repository for the University of Wollongong. For further information contact the UOW Library: research-pubs@uow.edu.au 


\title{
Integrated life cycle cost method for sustainable structural design by focusing on a benchmark office building in Australia
}

\author{
Abstract \\ Cost has been traditionally known as a key factor that needs to be considered in the decision making \\ process. Recent awareness in environmental problems has highlighted the need for considering \\ environmental impacts into the process of making choices. However, far too little attention has been paid \\ to reflect the environmental impact and the building cost into the decision making process. As such, this \\ study proposed a method that integrates and considers the environmental cost and building cost in the \\ structural design process. This method takes into account the cost associated with building materials, \\ construction methods and amount of embodied carbon emission during the life cycle of buildings. The \\ current study analysed the effects of two construction systems (Flat slab and waffle slab) and two \\ structural materials (Normal concrete and Ultra-lightweight concrete) on overall costs of a typical high \\ rise concrete structure (15-story office building) in Australia (NS11401.1 2014). The results show that the \\ office building designed with lightweight construction method (waffle slab) and normal concrete (Normal \\ weight) has a lower life cycle cost (50 year lifespan) in comparison with the other design alternatives. It \\ was found that an appropriate selecting of construction forms and type of concrete can save up to $7 \%$ of \\ the cost of material consumption, $5 \%$ of the total energy consumption expense, and $5 \%$ of the $\mathrm{CO}_{2}-\mathrm{e}$ \\ emissions of the building across all five major cities. This study demonstrates a method to quantify the \\ potential impact of Ultra-lightweight concrete has on the life cycle cost and carbon emissions of \\ commercial buildings. The proposed methodology to assess life cycle cost and environmental impact can \\ be used as a supporting tool in selection of efficient construction methods and structural materials over \\ the lifetime of building.

\section{Disciplines} \\ Engineering | Science and Technology Studies

\section{Publication Details} \\ Robati, M., McCarthy, T. J. \& Kokogiannakis, G. (2018). Integrated life cycle cost method for sustainable \\ structural design by focusing on a benchmark office building in Australia. Energy and Buildings, 166 \\ 525-537.
}




\title{
Integrated life cycle cost method for sustainable structural design by
}

\section{focusing on a benchmark office building in Australia.}

\author{
Mehdi Robati $^{* 1,2,3}$, Timothy J McCarthy ${ }^{1}$, Georgios Kokogiannakis ${ }^{2}$ \\ ${ }^{1}$ School of Civil, Mining and Environment, Faculty of Engineering and Information Sciences, \\ University of Wollongong, Australia \\ ${ }^{2}$ Sustainable Buildings Research Centre (SBRC), University of Wollongong, Australia \\ ${ }^{3}$ Faculty of Built Environment, University of New South Wales, Australia \\ *Corresponding author. Tel.: +61 420477662. \\ E-mail address: mr329@uowmail.edu.au (Mehdi Robati)
}

\begin{abstract}
Cost has been traditionally known as a key factor that needs to be considered in the decision making process. Recent awareness in environmental problems has highlighted the need for considering environmental impacts into the process of making choices. However, far too little attention has been paid to reflect the environmental impact and the building cost into the decision making process. As such, this study proposed a method that integrates and considers the environmental cost and building cost in the structural design process. This method takes into account the cost associated with building materials, construction methods and amount of embodied carbon emission during the life cycle of buildings. The current study analysed the effects of two construction systems (Flat slab and waffle slab) and two structural materials (Normal concrete and Ultra-lightweight concrete) on overall costs of a typical high rise concrete structure (15-story office building) in Australia (NS11401.1 2014). The results show that the office building designed with lightweight construction method (waffle slab) and normal concrete (Normal weight) has a lower life cycle cost (50 year lifespan) in comparison with the other design alternatives. It was found that an appropriate selecting of construction forms and type of concrete can save up to $7 \%$ of the cost of material consumption, $5 \%$ of the total energy consumption expense, and $5 \%$ of the $\mathrm{CO}_{2}$-e emissions of the building across all five major cities. This study demonstrates a method to quantify the potential impact of Ultra-lightweight concrete has on the life cycle cost and carbon emissions of commercial buildings. The proposed methodology to assess life cycle cost and environmental impact can be used as a supporting tool in selection of efficient construction methods and structural materials over the lifetime of building.
\end{abstract}

Key word: Life cycle analysis, $\mathrm{CO}_{2}$-e emissions, life cycle cost, Ultra-lightweight concrete. 


\section{Introduction}

The construction and building industry is responsible for a large part of the environmental burden because the Australian building sector, for example, uses almost $20 \%$ of Australia's annual energy consumption and produces $23 \%$ of the Greenhouse Gases (GHG) (ABCB 2016). This situation will become even more critical due to the increasing number of houses (more than 3.3 million) resulting from the fast growth of population (NHSC 2011). A reduction in GHG is a vital need for Australia because the nation committed to cope with carbon mitigation by $26-28 \%$ below the 2005 level by 2030 during the Paris UN Climate Conference (DEE 2015). These growing pressures for ecological accountability have led to greater efforts to address the challenges associated with mitigation of $\mathrm{CO}_{2}$-e emissions in the building industry in Australia (DEE 2015; Robati et al. 2017; Yu et al. 2017). Moreover, the need to assess the energy performance of buildings has extended from simply calculating the energy consumption during the operational phase to assessing their impacts over whole life cycle of buildings (Fraile-Garcia et al. 2017; Tian 2013; Tian \& de Wilde 2011; Zuo et al. 2017).

Sustainability covers the environmental, social and economic aspects and most studies focus on the environmental and economic aspects of buildings by utilising Life Cycle Environmental Assessment (LCEA) and Life Cycle Cost Assessment (LCCA) (Akbarnezhad \& Xiao 2017; Fraile-Garcia et al. 2017; Zuo et al. 2017). Indeed, some studies have tried to optimise the structural design of buildings by considering their economic and environmental aspects (Cha et al. 2008; Hahn et al. 2010; Ji et al. 2014; Saling et al. 2002); they have proposed a conceptual framework to measure sustainability by selecting the optimal product design and simultaneously considering the environmental impact and costs of the products. Some other studies 
have employed quantitative methods to determine the embodied $\mathrm{CO}_{2}$-e emissions and cost incurred by selection of structural design alternatives through the lifetime of buildings (Ferreiro-Cabello et al. 2016; Fraile-Garcia et al. 2015; Fraile-Garcia et al. 2016). The results of these studies have shown that the embodied carbon emissions and costs of buildings were affected by the selection of structural alternatives (e.g. materials used, structural system selected and height of the building) on the decisionmaking process.

Others propose to evaluate the environmental and economic impacts by converting embodied $\mathrm{CO}_{2}$-e emissions into a momentary term over various stages of the building life cycle (Chou \& Yeh 2015; Gu et al. 2008; Hong et al. 2013; Itsubo \& Inaba 2003; Ji et al. 2014; Kim et al. 2012; Silvestre et al. 2014). Hong et al. (2012) proposed to integrate the cost and $\mathrm{CO}_{2}$-e emissions associated with building structural design (using different grades of concrete 21-30 MPa), while Chou and Yeh (2015) studied the environmental impacts associated with the life cycle of two construction methods (prefabrication and cast in place) by focusing on the consumption of fuel, electricity, and water.

Some research studies have previously quantified the effect that the structural materials have on the whole life energy performance of buildings (Appleby 2012; Bekas et al. 2015; DIIS 2013; Kaziolas et al. 2015); these studies have employed an optimisation method to minimise life cycle cost and energy associated with the structural design of buildings. The results of these studies have shown that basic design decisions about structural elements (type of floor, shape of core servers, arrangements of columns, and heights of beams) have a direct impact on the energy consumption of buildings. For example, Aye et al. (2012) studied the life cycle energy usage for three forms of building construction in Melbourne, Australia; they 
considered an eight-story multi-residential building with three different construction systems: modular prefabricated timber, conventional concrete construction, and modular prefabricated steel (Aye et al. 2012) and showed that a steel structure caused a 50\% increase in embodied energy compared to a concrete structure, but the steel structure reduced material consumption up to $78 \%$ by mass compared to the concrete structure. Hajdukiewicz et al. (2015) studied the structural and environmental performance of operating a building; they used a monitoring method for educational buildings that were mainly built with in situ and precast concrete, and showed there was a distinct lag between the outdoor and indoor air temperature in the monitored elements. They also pointed out the positive role that Ground Granulated Blast furnace Slag (GGBS) had in reducing the internal peak temperatures, and concluded by showing that the thermal mass used in the floor systems slowed the flow of heat through the elements and caused a temperature lag in the system.

Previous studies have highlighted the relative impact that decision making has on energy consumption, environmental performance, and life cycle cost of buildings, but there is still no study which uses every aspect to determine the impact of structural design on energy performance, life cycle $\mathrm{CO}_{2}$-e emissions, and life cycle costs in an integrated context for commercial buildings. Therefore, this study proposes to include the $\mathrm{CO}_{2}$-e emissions of a building structure over its lifetime as an environmental cost in order to provide a quantitative value for evaluating the global environmental impact made by different building structures in five Australian climate zones.

This study is divided into different parts. The first part is the methodology which describes the method used to assess the integrated life cycle and analyse the whole of life costs associated with the research parameters. Section 3 describes the 
calculations of $\mathrm{CO}_{2}$-e emissions associated with the building structure, energy modelling, and life cycle cost analysis. The results and discussion about the key findings associated with the research parameters are summarised in section 4 .

\section{Methodology}

Commercial and office buildings are built to last for several decades, but over such a long period of time a building utilises a wide range of resources and energy intensive processes. Cost effectiveness is a key component of structural design at the initial stage of projects, so this study analyses the life cycle cost and environmental impacts associated with a typical benchmark office building in Australia. This benchmark building is one of four benchmarking buildings proposed by the National standard Organization (NSDO) in Australia (NS11401.1 2014).

Figure 1 summarises all costs associated with a product or project over its lifetime, including the concept and definition, design and development, manufacturing and installation, operational and maintenance, and the disposal costs (AS/NZ4536 2014). This study quantifies the life cycle costs associated with the office building by considering alternatives structural materials and forms of construction; the life cycle costs include the initial costs, and the operational and maintenance costs (as shown in Equation 1).

$$
L C C A=P V_{C P . C}+P V_{O P . C}+P V_{R e p . C}
$$

LCCA $=$ Life Cycle Cost

$\mathrm{PV}_{\mathrm{CP.C}}=$ Present value of capital costs (initial cost)

$\mathrm{PV}_{\text {OP.C }}=$ Present value of operational costs (over 50 year lifetime)

$\mathrm{PV}_{\text {Rep.C }}=$ Present value of replacement costs (over 50 year lifetime) 


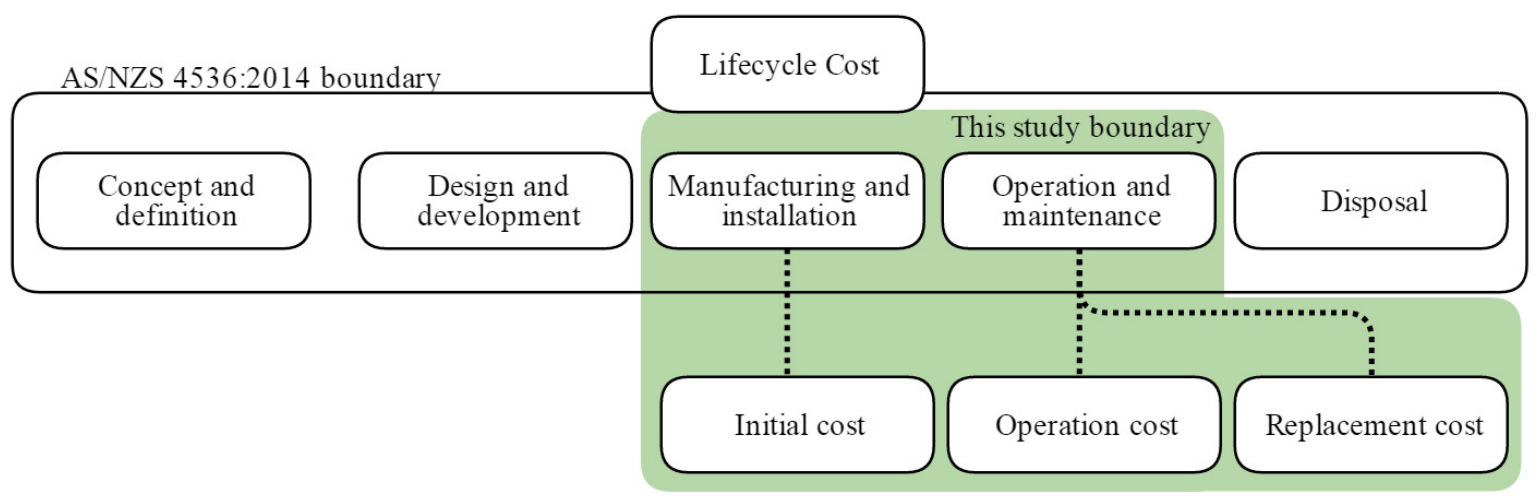

Figure 1 Life cycle cost of building

The initial cost included materials and construction expenses; the operational and maintenance cost consist of utilities cost and repair costs that occur only every several years over a 50 year service life. The costs associated with a feasibility study (concept and definition), and the design, development, and discarding (disposal) are excluded from the scope of this study.

The environmental impact associated with the benchmark building was derived in terms of $\mathrm{CO}_{2}$-e emissions because they contribute more climate change than the other GHGs (methane, nitrous oxide, hydrofluorocarbons, perfluorocarbons and sulphur hexafluoride) (IPCC 2014; UNFCCC 2008). The environmental costs represent the cost of $\mathrm{CO}_{2}$-e emissions per ton which are derived from the lifetime carbon emissions of buildings. Equation 2 is a method for estimating the cost associated with $\mathrm{CO}_{2}$-e at each stage of a building's life.

$$
E_{\text {IM }}-e=P V_{I C . C O 2}+P V_{O P C . C O 2}
$$

EIM $_{\mathrm{CO} 2-\mathrm{e}}=$ Environmental impact $\left(\mathrm{CO}_{2}\right.$-e emissions $)$ costs

$\mathrm{PV}_{\mathrm{IC} . \mathrm{CO} 2}=$ Present value of initial $\mathrm{CO}_{2}$-e cost

$\mathrm{PV}_{\mathrm{OPC} . \mathrm{CO} 2}=$ Present value of operational $\mathrm{CO}_{2}$-e costs (over 50 year lifetime)

This comparison framework is used to integrate the life cycle costs and environmental impact of several structural design alternatives and then choose the best alternatives. The environmental impact costs are estimated from the total GHGs 
emitted over the building lifetime and the present carbon value (as shown in Figure 2). In this study the total GHGs emitted by the building consist of the state of the product, the construction stage, and use stage.

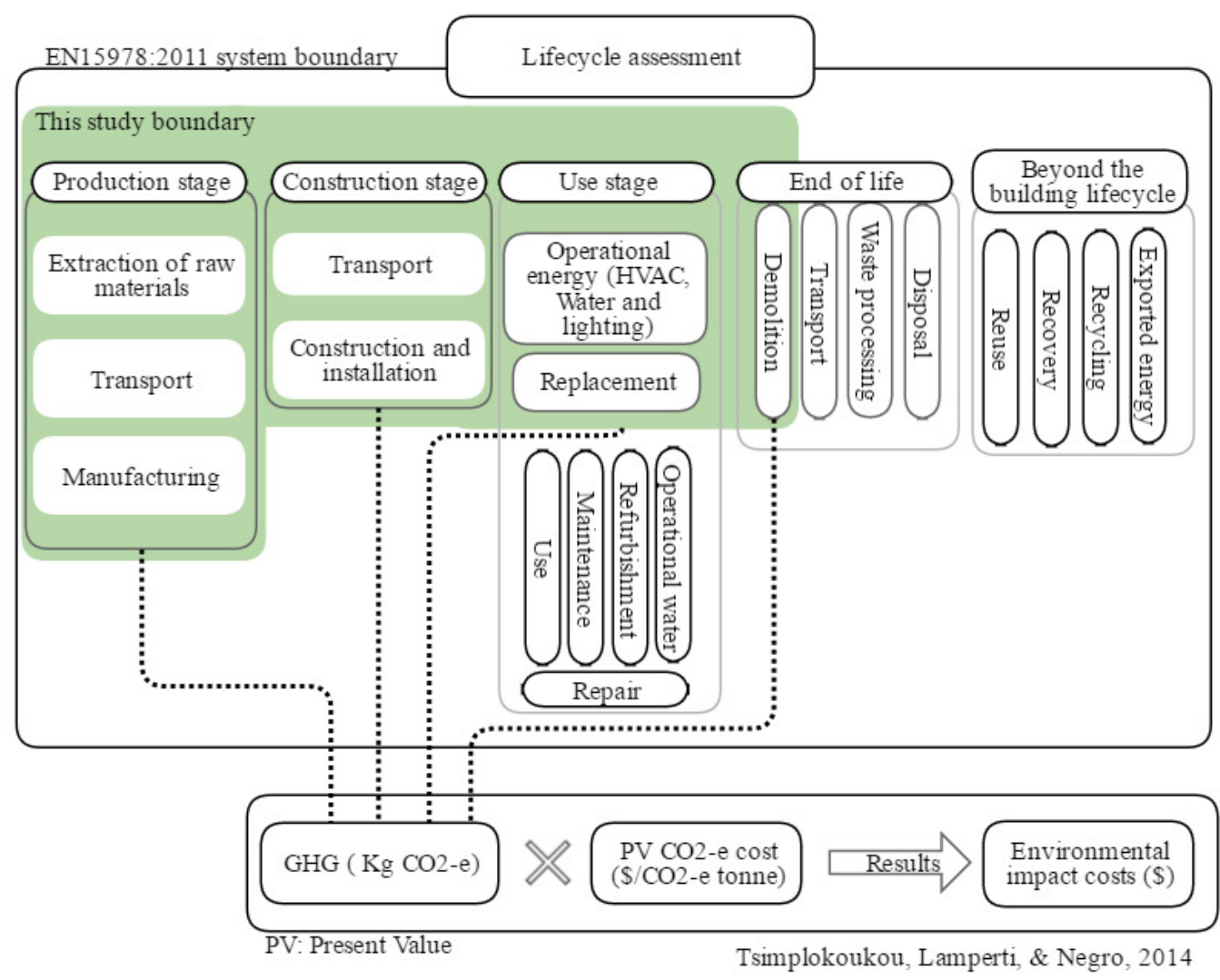

Figure 2 Environmental cost analysis method

Figure 3 shows how the global assessment framework provides a method to combine the life cycle costs (initial costs, and operational and maintenance costs) and environmental impact costs (the total equivalent $\mathrm{CO}_{2}$-e emissions cost) over the lifetime of the building. This method compares the global costs across alternative building designs and delivers an outcome of cost results as a single global assessment parameter. This comparison framework integrates the results of life cycle costs and the environmental impacts of several structural design alternatives to help select the best alternatives. 


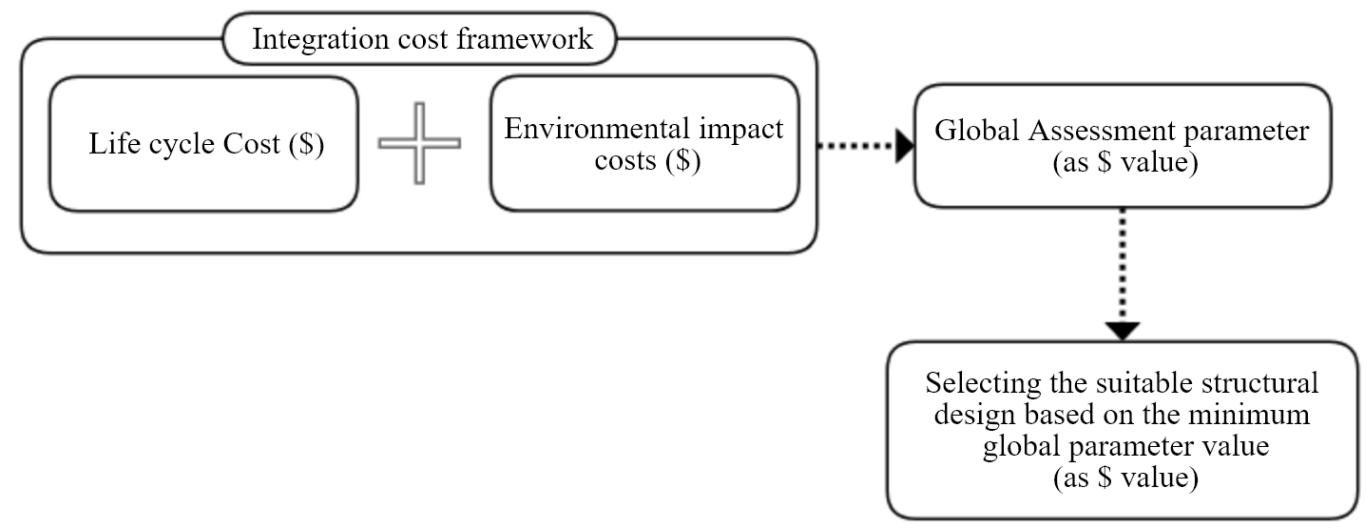

Figure 3 Global assessment framework

\subsection{Initial cost assessment method}

The initial cost of the building includes the materials, transportation, and construction process. The quantities of building materials are from NS11401.1 (2014), the quantity of concrete and steel reinforcement comes from the detailed structural design (shown in Appendix B), and the input data to estimate these costs comes from the commonly used Australian construction cost guides and published literature (Cordell 2016; Rawlinsons 2016). The base year taken was 2016, and the input climate data were classified based on five different climate zones across Australia: Darwin (climate zone 1); Brisbane (climate zone 2); Sydney (climate zone 5); Melbourne (climate zone 6); Canberra (climate zone 7) (NS11401.1 2014). The cost of Ultra-lightweight concrete was calculated based on its unique mix design (proposed as mixes 32 and 36 in (Robati et al. 2016)), and the relative cost was collected from supplier price lists such as Eastchem (2017) (supplier of hollow fly ash cenosphere) and Boral (2017) (supplier of other components). A summary of the building materials and associated costs and quantities are provided in Table 1 . The quantities of materials used in the building (items 8 to 16) are derived from NS 11401.1 (NS11401.1 2014), and the estimated quantities of structural materials (concrete and steel reinforcement) for the Flat slab and Waffle slab are based on a 
detailed structural analysis. In terms of structural analysis and design, a detailed concrete structure design is considered by following the Australian Standards Concrete structures (AS3600 2009). Two main aspects of this code, i.e., the strength and serviceability, were taken into the account during the structural design of this building. In this study the amount of live load was sourced from the Australian and New Zealand standard for imposed actions (AS/NZ1170.0 2002). The live loads for office parking, and work rooms are $5 \mathrm{kPa}$ and $3 \mathrm{kPa}$, respectively. The dead load for the concrete members was obtained by multiplying the volume of the member with the unit weight of concrete. Wind loads on the building were determined in accordance with the Australian and New Zealand standard wind actions (AS/NZ1170.2 2011). The magnitude of wind pressure on the structure was calculated based on height above ground, size, importance, and location. The importance level of the building is level 3 , due to the consequences of failure based on the expected high rate of occupancy and use AS/NZ1170.1 (2002). For ultimate limit states and serviceability, the annual probability exceedance came from AS/NZ1170.2 (2011), Table 3.1, for designed working life of 50 years in a cyclic zone in Australia. To calculate the wind load, Zone D is used to ensure there is enough strength in the structure as well as validating the potential of constructing the building in other zones. For the loading conditions, a combination of actions is used to check the serviceability and strength of the building in accordance with clause 4.2.1 and 4.2.2 of the AS/NZ1170.2 (2011). The CAD package Etabs, Safe and a Microsoft Excel spreadsheet were used to verify the minimum requirements of the concrete design code. 
Table 1 summary of building materials and unit costs

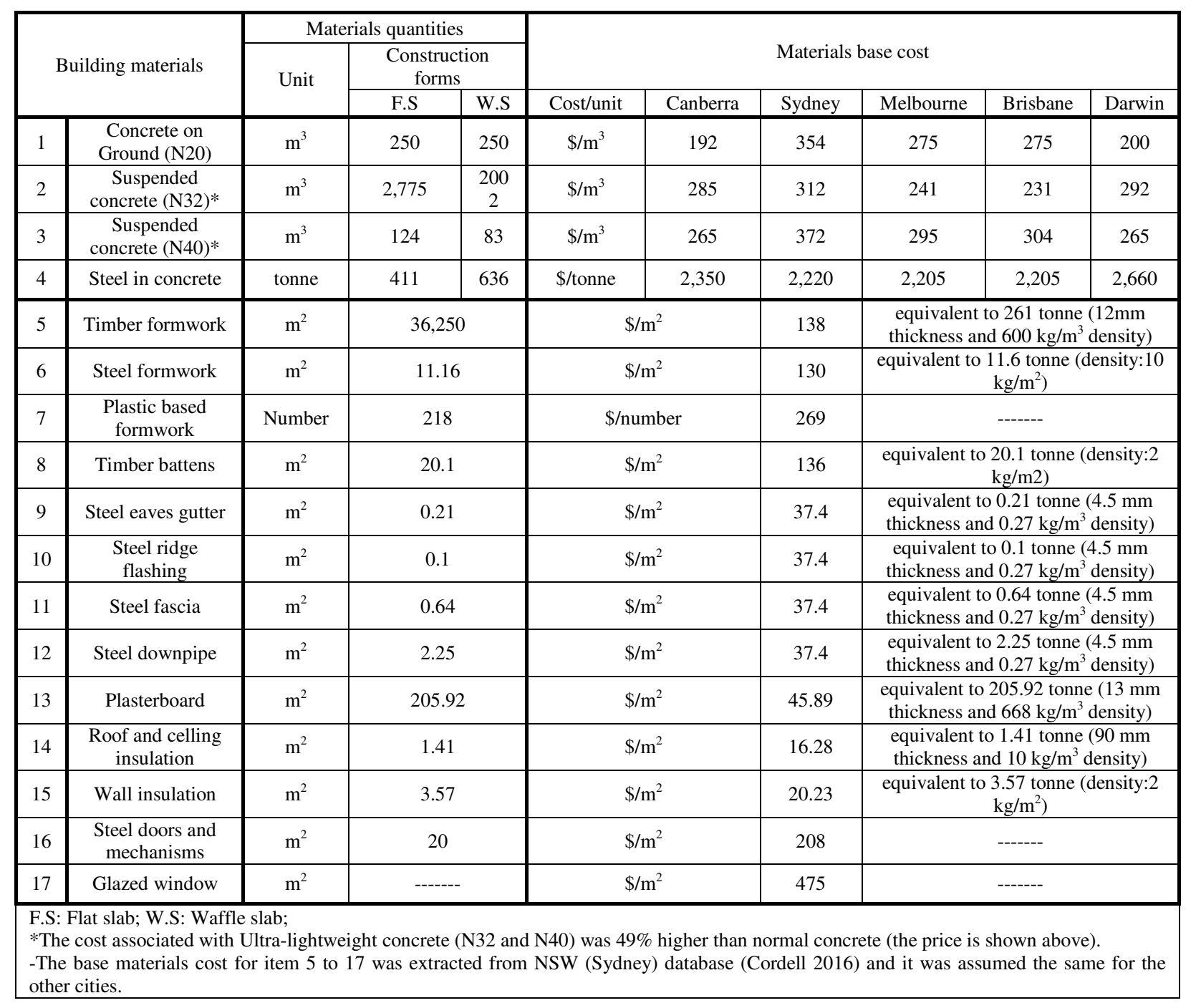

\subsection{Operational and maintenance cost assessment method}

The operating costs of the building is based on the energy consumed over a 50 year service life, while the operating energy over the life cycle of buildings is calculated based on the simulated annual heating and cooling load. The estimated annual energy used was multiplied by the relative energy market forecasts up to 2040 (Economics 2015; Jacobs 2016) and the future method of calculation to extend the estimated costs of energy from 2040 to 2066 (a 50 year lifetime). Equation 3 was used to determine the present operational costs over a 50 year, although the future costs were then discounted by $7 \%$ as a nominal per year (Lawania \& Biswas 2016). 


$$
P V_{O P . c o s t}=\sum_{y=1}^{50} \frac{F E C}{(1+d)^{n}}
$$

$\mathrm{PV}_{\text {OP.cost }}=$ Present value of operational costs

$\mathrm{FEC}=$ future energy cost (based on the market forecast and future cost analysis)

$\mathrm{d}=$ discounted rate per year

$\mathrm{n}=$ the appropriate number of years

The present value associated with maintenance (replacement) costs is estimated for glazed windows (25 years) and plasterboard (35 years), both of which have a shorter lifetime than the building (50 years) (Rauf \& Crawford 2012). The construction materials in Table 1 have a higher life expectancy than the whole building (50-year), and therefore the costs of ongoing repair, replacement, refurbishment, and external site development were excluded from this study.

\subsection{Environmental costs estimation method}

The most common category for environmental impact used in life cycle assessment is global warming, so this study used $\mathrm{CO}_{2}$-e emissions as a key method for assessing the environmental impact of various structural design alternatives. The calculated $\mathrm{CO}_{2}$-e emissions at each stage of the designed buildings (production, construction, operation and end of life demolition) were included. For the production and construction phases, the $\mathrm{CO}_{2}$-e emissions that are associated with manufacturing and transporting the construction materials were estimated. The embodied $\mathrm{CO}_{2}-\mathrm{e}$ emissions associated with construction work, transportation, and final demolition at the end of life were taken in this study to be at a level of $1 \%$ of the lifetime $\mathrm{CO}_{2}$-e emissions (Ruuska \& Häkkinen 2015; Sartori \& Hestnes 2007).

During the operational stage, energy conversion results in the release of greenhouse gas emissions were estimated by using the national emissions factor proposed by the Australian National Greenhouse Accounts (DEE 2016). The emissions factor used to convert the consumption of operational energy into $\mathrm{CO}_{2}$-e emissions is a function of 
the electricity purchased and consumed in 2015 (Lawania \& Biswas 2016). Electricity is a dominant energy source in the benchmark building to provide the required cooling load; other energy sources do not contribute to the total energy used (Robati et al. 2017). It must be noted that the emissions projections are inherently uncertain, and this uncertainty increases into the projected future emissions. Based on Australia's report into emissions projections(DEE 2016), future emissions from the combustion of fuels to generate electricity are predicted at a level of $186 \mathrm{Mt} \mathrm{CO}_{2^{-}}$ e emissions in 2030, which is roughly equivalent to 2015 levels. As such, this study uses a base year of 2015 to estimate the $\mathrm{CO}_{2}$-e emissions associated with the energy usage stage of a building.

The values related to the embodied $\mathrm{CO}_{2}$-e emissions of materials is extracted from the accessible Australian literature and databases (Alcorn 2003; AusLCI 2016; Crawford 2011; eTool 2014; Hammond et al. 2011; Moussavi Nadoushani \& Akbarnezhad 2015; Robati et al. 2016). The mean distance from manufacturing companies to the site (the central business district for each city) is measured using the Google map tools (Poinssot et al. 2014). In the last stage, the environmental impact is converted into costs. The price of $\mathrm{CO}_{2}$-e emissions is based on the Adams et al. (2014) method and the Australia Emissions Trading Scheme (Combet 2012) with an inflation rate of $3 \%$ per year (RBA 2016). Future $\mathrm{CO}_{2}$-e emissions is discounted at 7\% as a nominal rate per year (Lawania \& Biswas 2016). Equation 4 provides a present value for the costs of $\mathrm{CO}_{2}$-e emissions over the lifetime of the buildings.

$$
P V_{\mathrm{CO}_{2}-e \text { cost }}=\sum_{y=1}^{50} \frac{\mathrm{CP}_{\mathrm{CO}_{2}-e^{*}(1+a)^{n}}}{(1+d)^{n}}
$$

$\mathrm{PV}_{\mathrm{CO} 2-\mathrm{e}}=$ Present value of $\mathrm{CO}_{2}-\mathrm{e}$ costs

$\mathrm{CP}_{\mathrm{CO} 2-\mathrm{e}}=$ Current $\mathrm{CO}_{2}$-e price

$\mathrm{a}=$ is the expected increase in price per year (inflation rate) 
$\mathrm{d}=$ discounted rate per year

$\mathrm{n}=$ the appropriate number of years

\subsection{Building Design and Construction}

The system for constructing the proposed 15 story office building is a mid-rise concrete structure (NS11401.1 2014); it has a square plan shape with a gross area of $1000 \mathrm{~m}^{2}$, and consists of twelve 3.30 metre high stories and three floors of parking (as shown in Figure 4). The geometry and construction materials are summarised in Table 2.

Table 2 Overall specification for the benchmark building

\begin{tabular}{ccc}
\hline Parameter & Unit & Specification \\
\hline Basement dimensions & $\mathrm{m}$ & $31.62 \times 31.62$ \\
Number of Stories & --- & 15 \\
Concrete slab on ground & $\mathrm{mm}$ & 200 \\
Concrete suspended slab & $\mathrm{mm}$ & 175 \\
Average elevation per floor & $\mathrm{m}$ & 3.3 \\
Total floor Area (including parking, Stairs \& & $\mathrm{m}^{2}$ & 15,000 \\
Verandas) & $\mathrm{m}^{2}$ & $8,807.1$ \\
Total habitable area (external dimensions) & -11 & 176 \\
Number of floors above ground level & & \\
Number of rooms & & \\
\hline
\end{tabular}

Figure 4 Template of 15-storey commercial office building as visualised in Design Builder 
The structural system is designed to meet the minimum needed to satisfy the national construction code (ABCB 2015; AS3600 2009; AS/NZ1170.0 2002)

Table 3 Summary of the structural design

\begin{tabular}{lccc}
\hline \multicolumn{1}{c}{ Construction form } & Flat slab (F.S) & Waffle slab (W.S) \\
\hline \multicolumn{2}{l}{$\begin{array}{l}\text { Column span distance (L) } \\
\text { Slab thickness (D) }\end{array}$} & $5.27 \mathrm{~m}$ & $5.27 \mathrm{~m}$ \\
\hline \multirow{2}{*}{$\begin{array}{c}\text { Concrete quantities } \\
(\mathrm{m} 3)\end{array}$} & $\mathrm{N} 20$ & $200 \mathrm{~mm}$ & $250 \mathrm{~mm}$ \\
\cline { 2 - 4 } & $\mathrm{N} 32$ & 250 & 250 \\
\hline Steel quantities (Tonne) & 3,005 & 2,002 \\
\hline & 124 & 679 \\
Cross section & 753 & \\
\end{tabular}

This current study evaluated the possible effects of normal and low-density concrete with a higher weight (Flat slab) and lower weight (Waffle slab) office structure when the most common (Normal Weight) and novel (ultra-lightweight) concrete materials are used. The types of concrete mix designs were extracted from previously published journal papers and databases (CCAA 2015; O'Moore \& O'Brien 2009; Robati et al. 2016; Wu et al. 2015; Yun et al. 2013) (shown in Table 3).

\subsection{Energy Modelling}

To analyse the energy over the lifetime of the project, this office building is modelled in DesignBuilder (energy simulation software) so that the effects of alternative structural systems on the energy consumption could be assessed. DesignBuilder, a user interface for the EnergyPlus dynamic thermal simulation engine requires hourly weather files while the required inputs for equipment and occupancy heat gains and schedules are extracted from (NS11401.1 2014) and ABCB (2015).

This study used the Building Code of Australia (BCA) "deemed to satisfy" approach to define the envelope construction of this building. The concrete thermal resistance 
and thermal mass, as two of the more prominent aspects of an energy analysis of building, are presented in Table 4 below.

Table 4 Benchmark building physical properties

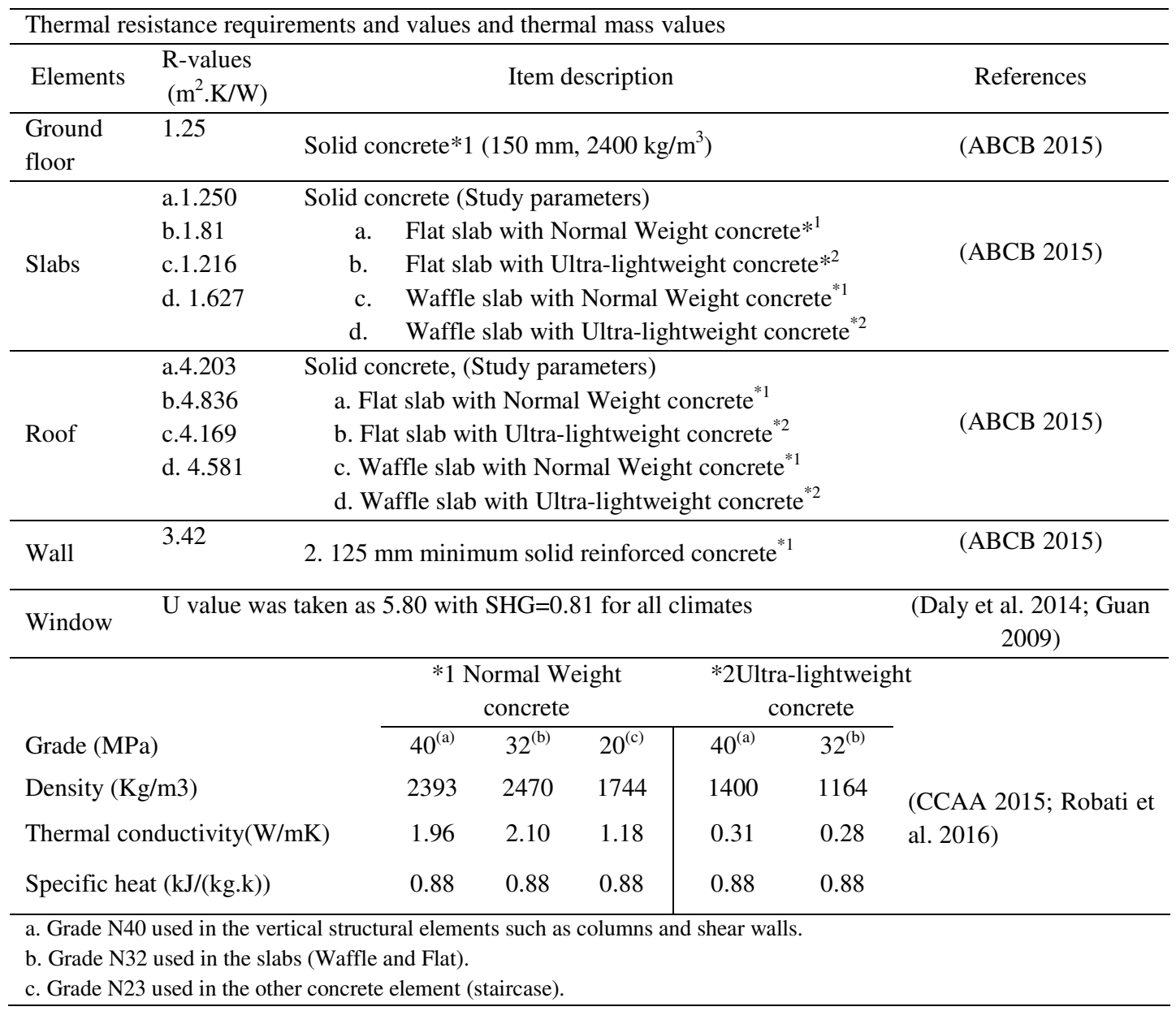

The internal energy loads in the office building form a large portion of energy usage and are significant input parameters in the energy analysis. Table 5 summarises the assumptions made to analyse the energy of the benchmark building. The schedules associated with the building are extracted from ABCB (2015). 
Table 5 Benchmark building simulation assumption

\begin{tabular}{ccc}
\hline Parameters & Key variables & References \\
\hline Lighting power density and schedule & $9(\mathrm{~W} / \mathrm{m} 2)$ & (ABCB 2015) \\
Occupancy density and schedule & $10(\mathrm{~m} 2 / \mathrm{person})$ & (ABCB 2015) \\
Equipment load and schedule & $15(\mathrm{~W} / \mathrm{m} 2)$ & (ABCB 2015) \\
Domestic hot water & $0.4(\mathrm{~L} / \mathrm{m} 2)$ & (ABCB 2015) \\
Infiltration & $0.28(\mathrm{ACH})$ & (Egan 2011) \\
Ventilation requirements and schedule & $10(\mathrm{~L} / \mathrm{s} /$ person) & \\
HVAC set point & $18-26^{\circ} \mathrm{C}$ & (ABCB 2015) \\
& Design builder & \\
HVAC & Simple HVAC, & (Daly et al. 2014) \\
& Auto size & \\
\hline
\end{tabular}

The results of modelling the benchmark building are shown in terms of total energy usage across different design alternatives. Here the total energy consumption is compared with national and states average energy usage to ensure that the predicted energy consumption is realistic (Pitt\&Sherry 2012), and then, at the final stage, the total energy consumption of the benchmark building across four climates is converted into the equivalent energy cost and environmental cost (equivalent $\mathrm{CO}_{2}$-e emissions).

\section{Results and Discussion}

\subsection{Lifetime environmental impacts}

Figure 5 is a comparison between whole of life $\mathrm{CO}_{2}$-e emissions for the benchmark office building across the five major climate zones. Note that the region dominated by heat such as Darwin has higher $\mathrm{CO}_{2}$-e emissions than the colder climate zones (Canberra and Melbourne) due to the high cooling load during the operational phase of the building in the hot climate where total $\mathrm{CO}_{2}$-e emissions are much higher than cold climates. Moreover, $\mathrm{CO}_{2}$-e emissions associated with these buildings reveal that Ultra-lightweight concrete released more $\mathrm{CO}_{2}$-e emissions than conventional concrete, and the heavier building with Ultra-lightweight concrete (200.low) produced highest carbon dioxide emissions $\left(\mathrm{CO}_{2}-\mathrm{e} / \mathrm{m}^{2}\right)$ across all five major cities. 
The NABERS (National Australian Built Environment Rating System) rating tool revealed that the environmental impact of these different design alternatives scored from 1 star (poor performance) to 3.5 stars (above average performance). The buildings located in Darwin and Canberra had the lowest (1 star) and highest (3.5 star) environmental impact rating, respectively, but more importantly, these ratings changed across various design alternatives in some regions; in Melbourne for instance, the lighter weight building made from novel concrete had a lower rating (2.5 star) than the others, which means that the selection of structural materials and the form of construction influences the overall environmental ratings.

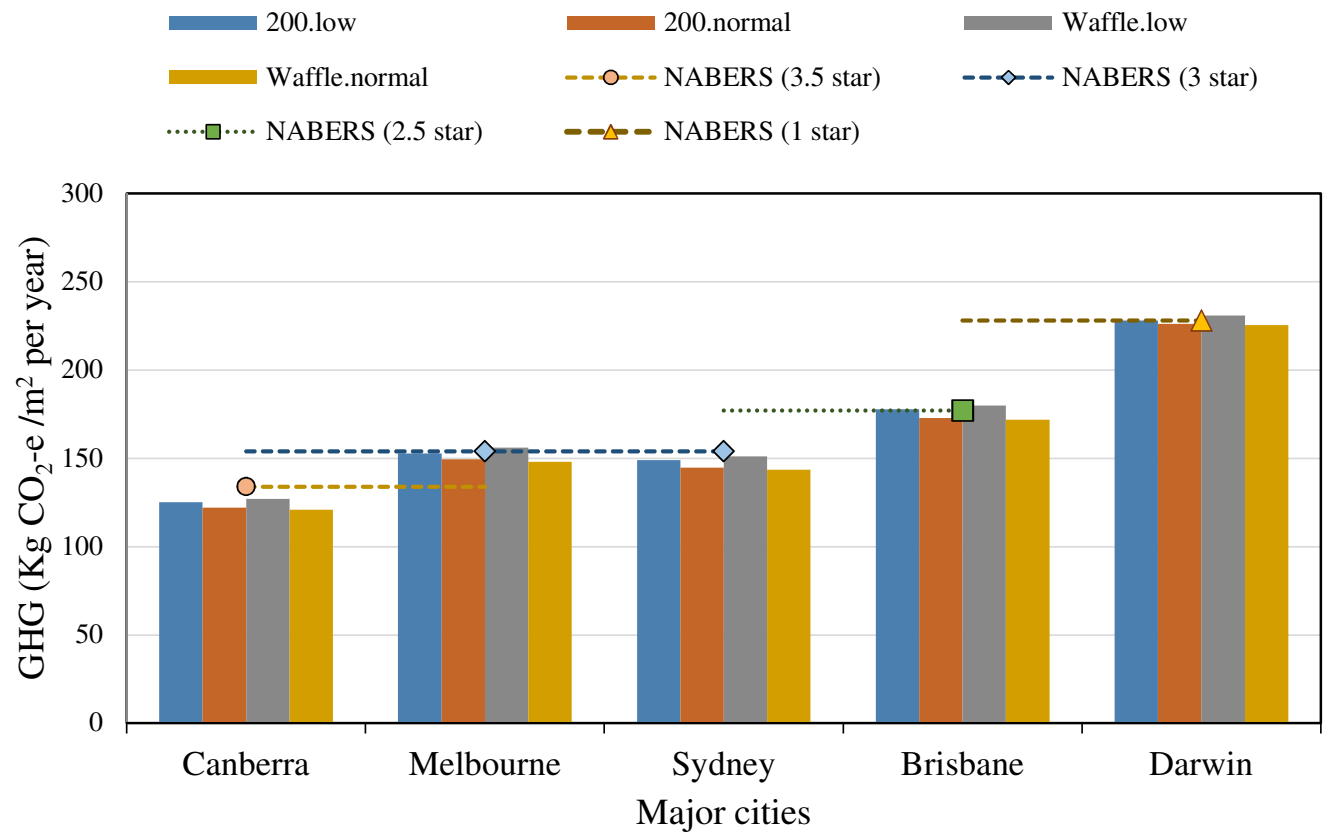

Source of the reference points NABERS (1.5, 2.5, 3 and 3.5 star rating) (Flores 2015)

Waffle.low: Lightweight structure (Waffle slab) with Ultra-lightweight concrete; Waffle.normal: Lightweight structure (Waffle slab) with Normal Weight concrete; 200.low: heavyweight structure (200mm Flat slab) with Ultra-lightweight concrete; 200.Normal: heavyweight structure (200mm Flat slab) with Normal Weight concrete.

\section{Figure 5 Annual GHG ( $\mathrm{CO}_{2}$-e emission) normalised by net internal area $\left(\mathrm{m}^{2}\right)$}

Figure 6 shows the $\mathrm{CO}_{2}$ emissions intensity associated with different phases of life cycle for two cities with the highest and lowest amount of $\mathrm{CO}_{2}-\mathrm{e} / \mathrm{m}^{2}$. The first bar shows the $\mathrm{CO}_{2}$-e emissions related to the production phase, the construction phase and the end of life (demolition) phase of the building; the second bar shows the $\mathrm{CO}_{2-}$ 
e emissions from operational phase of the building over a 50 year lifetime, and the last bar is the whole life $\mathrm{CO}_{2}$-e emissions for each alternative design. These results reveal how the range of $\mathrm{CO}_{2}$-e emissions for the buildings is influenced by changes in the type of concrete and type of construction. For instance, the Lightweight structures designed with Ultra-lightweight concrete had higher $\mathrm{CO}_{2}$-e emissions $(5 \%$ in Canberra and 2\% in Darwin) than the other design alternatives, whereas the Lightweight structure made from Normal weight concrete (Waffle.Normal) has the lowest $\mathrm{CO}_{2}$-e emissions across both cities. This trend can be seen in the other three main cities (as shown in Appendix A).
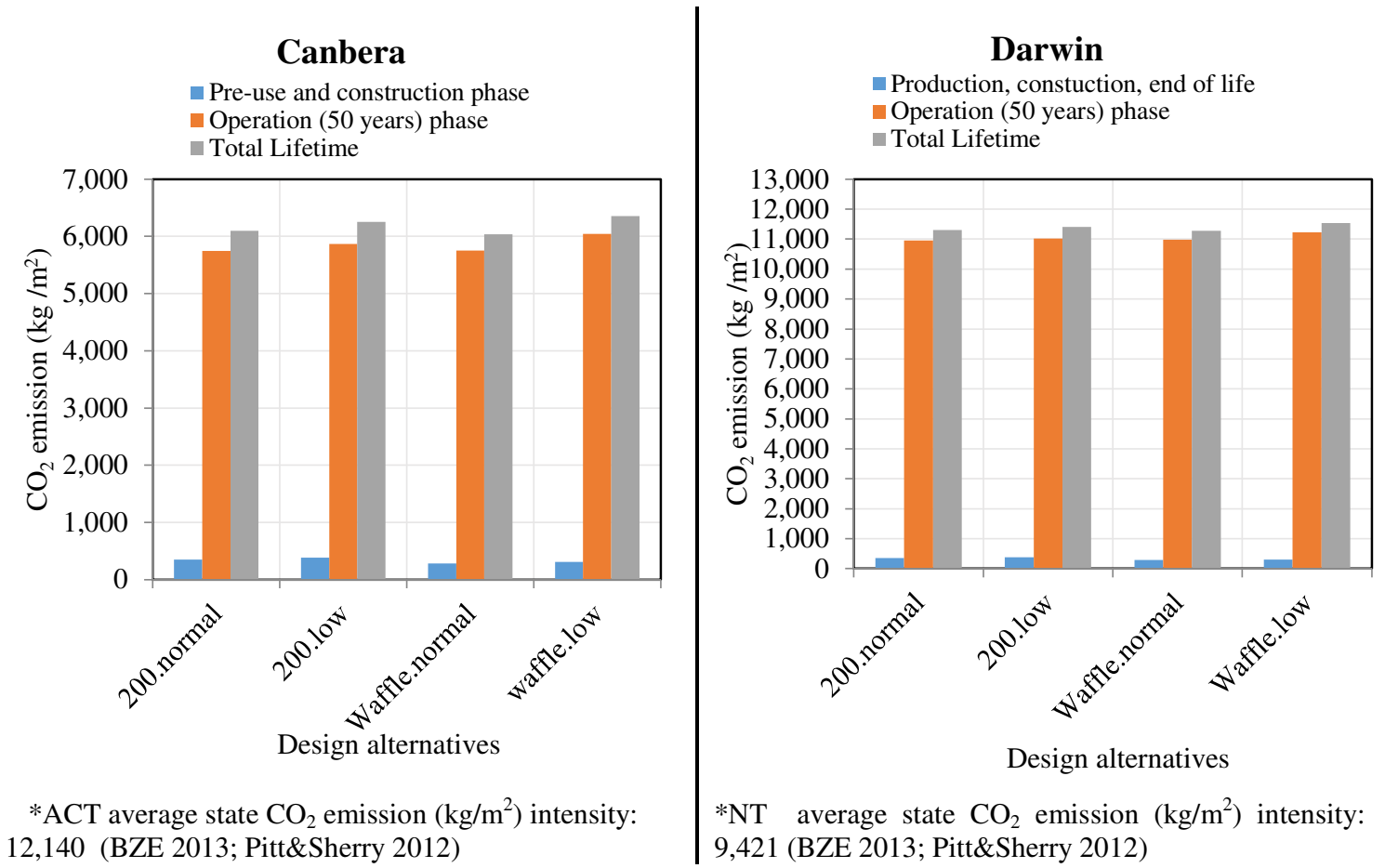

Waffle.low: Lightweight structure (Waffle slab) with Ultra-lightweight concrete; Waffle.normal: Lightweight structure (Waffle slab) with Normal Weight concrete; 200.low: heavyweight structure (200mm Flat slab) with Ultra-lightweight concrete; 200.Normal: heavyweight structure (200mm Flat slab) with Normal Weight concrete.

Figure 6 Life cycle $\mathrm{CO}_{2}$ emissions normalised by the gross floor area and separated by the type of concrete and method of construction.

\subsection{Present value Environmental costs of buildings}

The environmental life cycle cost includes the total cost associated with $\mathrm{CO}_{2}$-e emissions over the whole life (50 years) of the office buildings. This study estimated 
the $\mathrm{CO}_{2}$-e emissions at the production (peruse), construction, use stage, and end of life demolition. The $\mathrm{CO}_{2}$-e emissions of the final phase was considered at a $1 \%$ level by previous studies (Ruuska \& Häkkinen 2015; Sartori \& Hestnes 2007). Figure 7 shows the present environmental life cycle cost for four design scenarios (different forms of construction and structural materials), and the present cost of $\mathrm{CO}_{2}-\mathrm{e}$ emissions (Australian dollars) per net internal area.

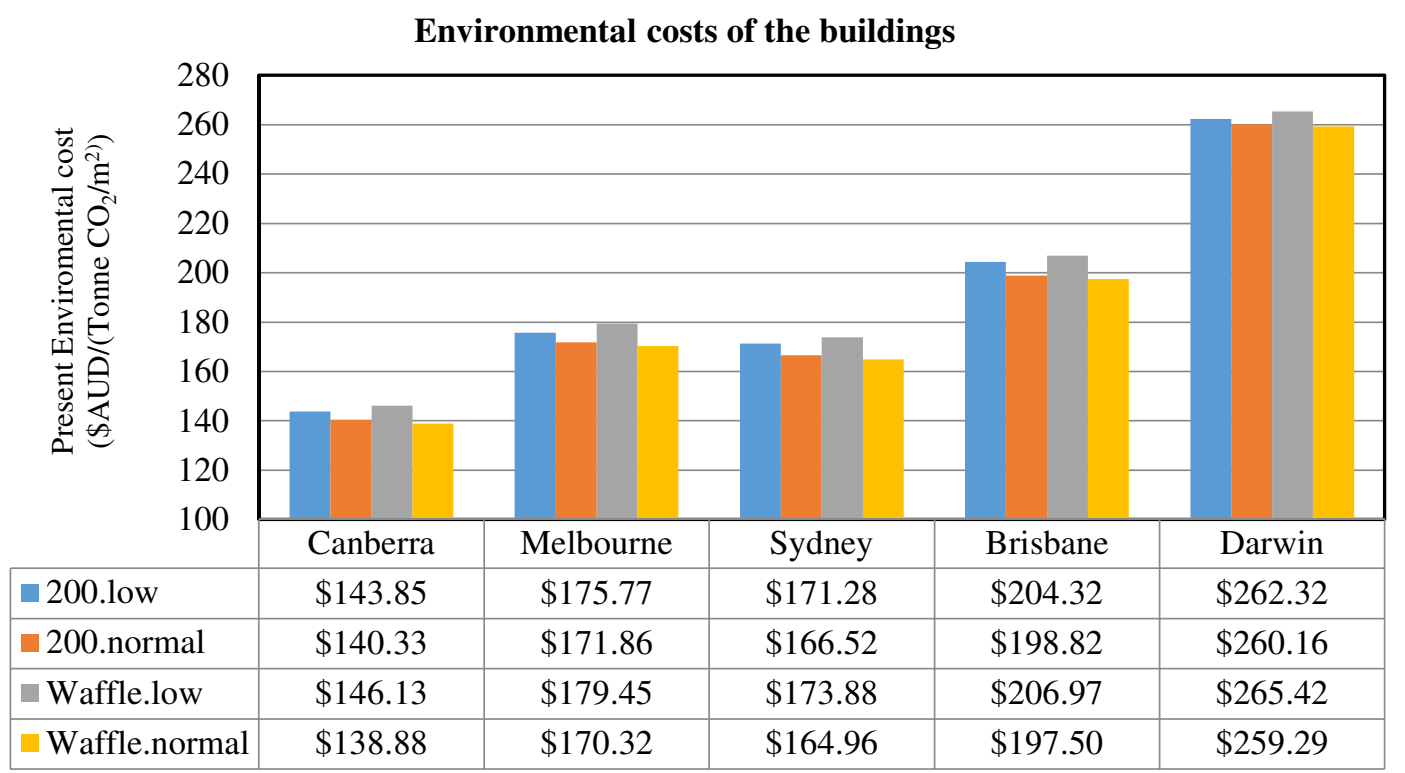

Waffle.low: Lightweight structure (Waffle slab) with Ultra-lightweight concrete; Waffle.normal: Lightweight structure (Waffle slab) with Normal Weight concrete; 200.low: heavyweight structure (200mm Flat slab) with Ultra-lightweight concrete; 200.Normal: heavyweight structure (200mm Flat slab) with Normal Weight concrete.

\section{Figure 7 Environmental cost of the buildings}

Figure 7 shows that the Lightweight building (Waffle slab) constructed with Ultralightweight concrete has the highest amount of carbon emission costs (\$AUD) per normalised $\mathrm{CO}_{2}$-e emissions for the net settlement area (Tonne $\mathrm{CO}_{2}-\mathrm{e} / \mathrm{m}^{2}$ ) over the lifetime of the buildings, while the Waffle slab with Normal weight concrete has the lowest carbon emission costs. This shows that Ultra-lightweight concrete can cost up to $5 \%$ more over the whole of life environmental costs than Normal weight (conventional) concrete, which means the type of concrete used is a large part of the total $\mathrm{CO}_{2}$-e emissions. For Melbourne, the total carbon cost per $\mathrm{m}^{2}$ (net internal area) 
of the building changed from 170 to 180 (\$AUD/ (Tonne $\mathrm{CO}_{2} / \mathrm{m}^{2}$ )) when Ultralightweight is used as the main structural material. This change in cost of $\mathrm{CO}_{2}$-e emissions also occurs when the heavier building consists of 200mm thick Flat slabs (200.normal and 200.low).

\subsection{Life cycle cost analysis}

\subsubsection{Capital costs}

This study evaluated the capital costs associated with Flat slab and Waffle slab construction methods and Normal and Ultra-lightweight concrete across five regions (as shown in Figure 8).

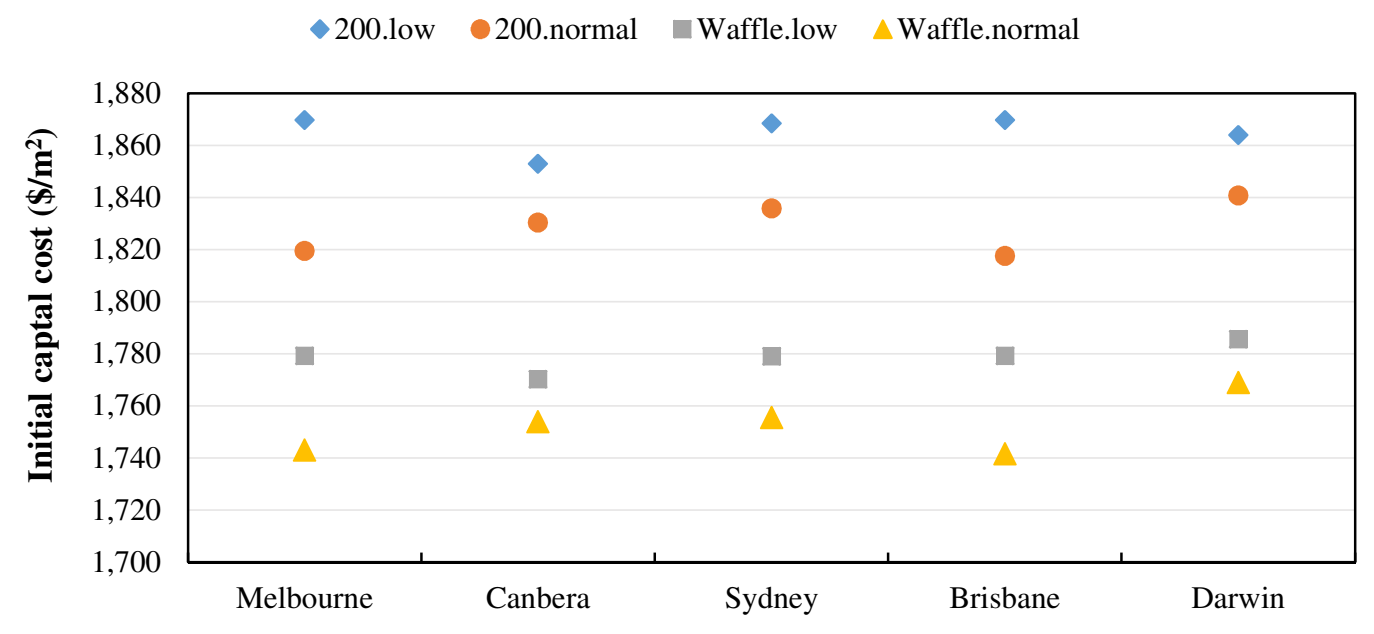

Figure 8 Initial capital costs (construction) of the building

The results show that the average cost of a Lighter weight structure (Waffle Slab) with Normal Weight concrete is less than the heavier structure (Flat slab). For example, the initial cost of the building in Melbourne with Waffle slab and Normal Weight concrete is $6 \%$ lower than the Flat slab with normal concrete (200.normal), however, Ultra-lightweight concrete in the structure resulted in higher capital cost in all five climate zones. The initial cost of the building with Flat slab with Ultralightweight concrete (200.low) is higher than the cost of the construction systems. As 
the literature highlights, the availability of supplementary cementitious materials used in Ultra-lightweight concrete is limited compared to Normal Weight concrete, so the costs are higher (Glavind 2012). For instance, the cost of Ultra-lightweight concrete used in this study is affected mainly by the price of Cenosphere (hollow particles from the production of fly ash) which is higher than the other concrete components (Eastchem 2017). Apart from the cost, there are still obstacles to the use of Lightweight and/or Ultra-lightweight concrete, i.e., regulatory, technical, and supply chain (Cabeza et al. 2013; Duxson \& Provis 2008; Van Deventer et al. 2012). There are several research programs currently aiming to remove these obstacles to allow for a wider use of Lightweight and/or Ultra-lightweight concretes (Huiskes et al. 2016; Yu et al. 2015), so it is worth considering when Ultra-lightweight concrete may become more available.

\subsubsection{Operating and maintenance costs of the buildings}

The present values associated with the operating expenses are derived from forecasts of energy consumption and energy prices; these simulations were used to determine the operational costs over the lifetime of buildings (50 years). The maintenance costs are compared to the present value and the cost of replacing materials with shorter lifespans than buildings (50 years), such as glazed windows (25 years) and plasterboard (35 years) (Rauf \& Crawford 2012). Figure 9 shows the costs associated with Energy consumption and the materials used across five cities in Australia. The cost analysis shows that Darwin with its warm winter and hot summer had the highest energy consumption, while Melbourne, with its mild temperature had lower energy consumption than the other cities; however, the operational costs are much higher than the replacement costs over the lifetime of the buildings. The energy performance was influenced by the methods of construction (Flat slab and Waffle 
slab) and the types of structural materials (concrete density: Normal Weight and Ultra-lightweight). The results show that selecting the right forms of construction and type of concrete could save $2.4 \%$ of the running costs (during lifetime) for the building in Darwin and 5\% for the other cities (Brisbane, Sydney, Melbourne, and Canberra). The Lightweight office building (Waffle) with Normal Weight concrete (Waffle.normal) has lower running costs than the alternatives, whereas the operating and replacement costs associated with the analysis reveal a consistently higher expenditure for the Waffle slab made from low density concrete (Ultra-lightweight).

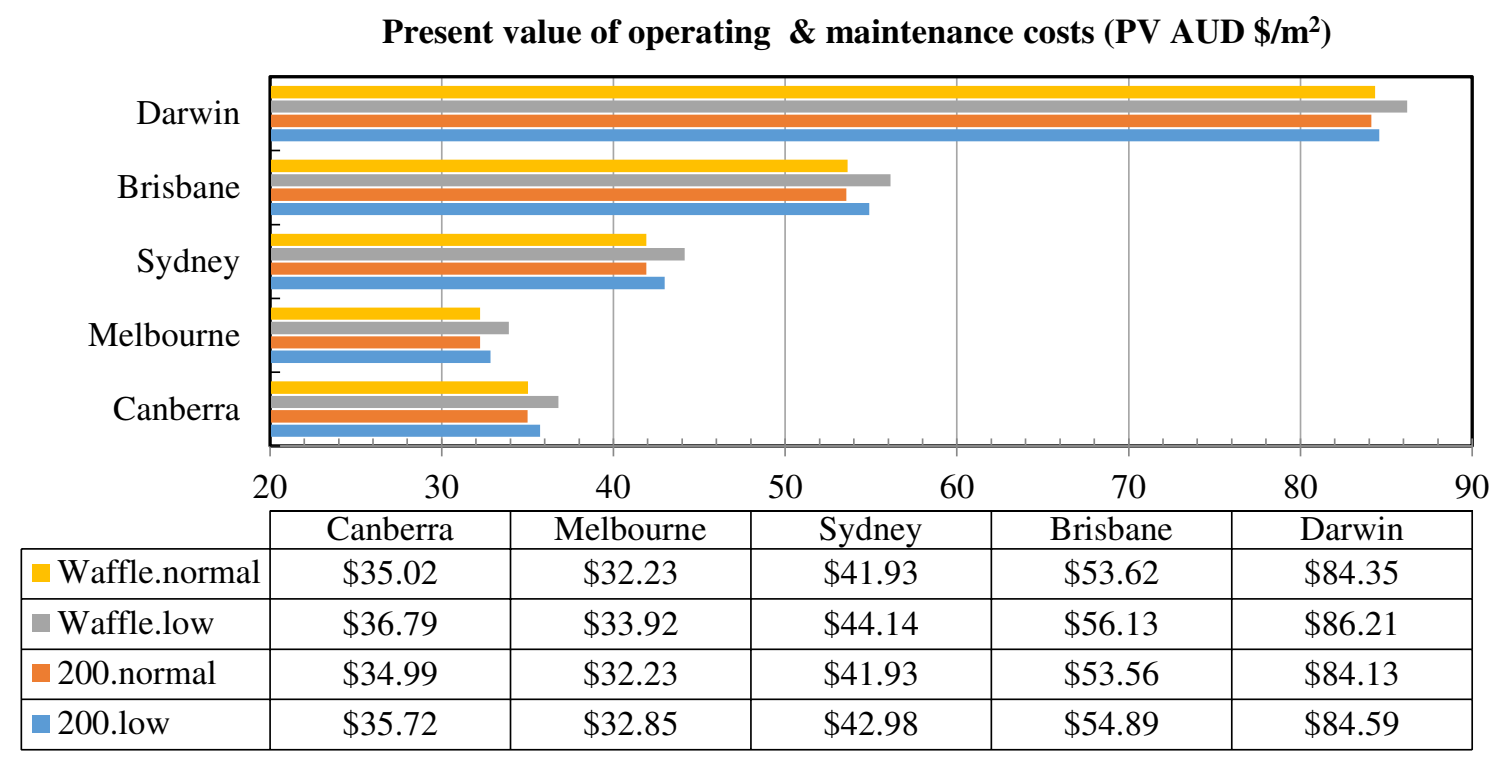

Figure 9 Present value of operational and replacement costs of the building

\subsection{Combined life cycle environmental and cost net present value}

Table 6 summarises the whole life cycle cost assessment of the office building across five major cities in Australia; these costs are presented as environmental costs and life cycle cost (a combination of capital cost, operating costs, and maintenance costs) per net internal area. These results indicate that the energy demand at the operational phase and capital phase are the highest proportion of costs over the 50 year lifetime of the building. The equivalent cost $\mathrm{CO}_{2}$-e emissions from production, construction, use, and demolition (end of life) can be up to $5 \%$ of the total cost of the buildings 
across all cities and design alternatives. The overall cost (LCCA+ Environmental cost) of the office building in Sydney ranged from to $4,017\left(\$ \mathrm{AUD} / \mathrm{m}^{2}\right)$ for the Waffle slab with normal concrete (Waffle.normal) to 4,189 (\$ AUD/m²) for the Flat slab with Ultra-lightweight concrete (200.low).

Table 6 whole life environmental and life cycle cost assessment of the building

\begin{tabular}{|c|c|c|c|c|c|c|c|}
\hline \multirow[t]{2}{*}{ Location } & \multirow[t]{2}{*}{$\begin{array}{l}\text { Type of } \\
\text { Building }\end{array}$} & $\begin{array}{l}\text { PV. Initial } \\
\text { cost }\end{array}$ & $\begin{array}{l}\text { PV.Operational } \\
\text { and } \\
\text { replacement } \\
\text { cost } \\
\end{array}$ & LCCA & $\begin{array}{c}\text { PV. } \\
\text { Environmental } \\
\text { cost }\end{array}$ & Total costs & \multirow{2}{*}{ बి } \\
\hline & & $\left(\$ \mathrm{AUD} / \mathrm{m}^{2}\right)$ & $\left(\$ \mathrm{AUD} / \mathrm{m}^{2}\right)$ & $\left(\$ \mathrm{AUD} / \mathrm{m}^{2}\right)$ & $\left(\$ \mathrm{AUD} / \mathrm{m}^{2}\right)$ & $\left(\$ \mathrm{AUD} / \mathrm{m}^{2}\right)$ & \\
\hline \multirow{4}{*}{ 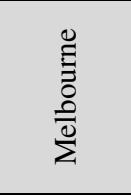 } & 200.normal & 1,819 & 1,611 & 3,431 & 172 & 3,603 & $+2 \%$ \\
\hline & 200.low & 1,870 & 1,642 & 3,512 & 176 & 3,688 & $+5 \%$ \\
\hline & Waffle.normal & 1,743 & 1,612 & 3,354 & 170 & 3,525 & ---- \\
\hline & Waffle.low & 1,779 & 1,696 & 3,475 & 180 & 3,655 & $+4 \%$ \\
\hline \multirow{4}{*}{ 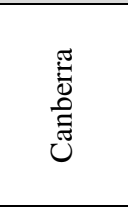 } & 200.normal & 1,830 & 1,750 & 3,580 & 140 & 3,720 & $+2 \%$ \\
\hline & 200.low & 1,853 & 1,786 & 3,639 & 144 & 3,783 & $+4 \%$ \\
\hline & Waffle.normal & 1,754 & 1,751 & 3,505 & 139 & 3,644 & ---- \\
\hline & Waffle.low & 1,770 & 1,840 & 3,610 & 146 & 3,756 & $+3 \%$ \\
\hline \multirow{4}{*}{ 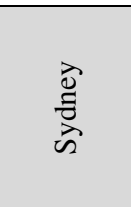 } & 200.normal & 1,836 & 2,096 & 3,932 & 167 & 4,099 & $+2 \%$ \\
\hline & 200.low & 1,868 & 2,149 & 4,017 & 171 & 4,189 & $+4 \%$ \\
\hline & Waffle.normal & 1,755 & 2,096 & 3,852 & 165 & 4,017 & ---- \\
\hline & Waffle.low & 1,779 & 2,207 & 3,986 & 174 & 4,160 & $+4 \%$ \\
\hline \multirow{4}{*}{ 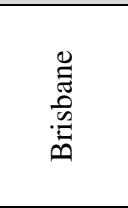 } & 200.normal & 1,817 & 2,678 & 4,495 & 199 & 4,694 & $+2 \%$ \\
\hline & 200.low & 1,870 & 2,744 & 4,614 & 204 & 4,818 & $+4 \%$ \\
\hline & Waffle.normal & 1,741 & 2,681 & 4,423 & 198 & 4,620 & ---- \\
\hline & Waffle.low & 1,779 & 2,806 & 4,585 & 207 & 4,792 & $+4 \%$ \\
\hline \multirow{4}{*}{ פ } & 200.normal & 1,841 & 4,206 & 6,047 & 260 & 6,307 & $+1 \%$ \\
\hline & 200.low & 1,864 & 4,229 & 6,093 & 262 & 6,356 & $+2 \%$ \\
\hline & Waffle.normal & 1,769 & 4,218 & 5,987 & 259 & 6,246 & ---- \\
\hline & Waffle.low & 1,786 & 4,311 & 6,096 & 265 & 6,362 & $+2 \%$ \\
\hline
\end{tabular}

This data indicates that a Waffle slab with an appropriate type of concrete (Normal Weight) can save up to $\$ 156$ per $\mathrm{m}^{2}$ (average value across all cities) in the total life cycle cost of the building across all five major cities, whereas the use Ultra-light weight concrete in the Flat slab increased the total costs of the building by almost $3 \%$ compared to Normal weight (conventional) concrete. Furthermore, the methods of 
construction and the structural materials are more tangible in colder climates that hot climates such as Melbourne and Darwin. A comparison between the Waffle slab and Flat slab, including Normal weight concrete, reveals that a lightweight structure with Normal weight concrete (Waffle.normal) can consistently save up to $2 \%$ in the total cost of the building, whereas the total cost associated with buildings constructed from Ultra-lightweight concrete across a lightweight structure (Waffle.low) and heavyweight structure (200.low) has not changed, and moreover, of the methods of construction and structural materials are more tangible in colder climates than hotter climates such as Melbourne and Darwin.

\section{Conclusion}

Despite the improvements in reducing $\mathrm{CO}_{2}$-e emissions for building designs, the guidance currently available to structural engineers on how to incorporate whole of life $\mathrm{CO}_{2}$-e emissions impact in building design is still limited. This study seeks to demonstrate how different structural alternatives affect the lifetime energy consumption, the materials used, the $\mathrm{CO}_{2}$-e emissions, and the costs in a typical office building in Australia. The two main parameters in this study are the method of construction (Flat slab and Waffle slab) and the type of concrete (Normal Weight and Ultra-lightweight) used as structural materials. Energy consumption figures (based on energy simulation results) and material replacement (25 years for glazed windows and 35 years for plasterboard) over the building lifespan are used to quantify the operational phase cost and $\mathrm{CO}_{2}$-e emissions by focusing on Australian energy prices and Australian national emissions factor.

This study finds that the total life cycle cost of buildings is heavily influenced by the selection of structural materials and system of construction, indeed we have shown that an appropriate building design can save almost $7 \%$ of the cost of material 
consumption, $5 \%$ of the total energy consumption expense, and $5 \%$ of the $\mathrm{CO}_{2}$-e emissions. A Lightweight building with a Waffle slab and Normal density cost less than the other buildings (LCCA and environmental costs) across five main climate zones; the heavyweight building with a Flat slab and Normal weight concrete is the second best design alternative, saving almost $3 \%$ in total costs compared to the other buildings.

The analysis of $\mathrm{CO}_{2}$-e emission costs shows that the use phase of the building is responsible for most $\mathrm{CO}_{2}$-e emissions, while the other building phase accounts for almost $5 \%$ of total $\mathrm{CO}_{2}$-e emission. The present value of $\mathrm{CO}_{2}$-e emissions varies from 6 to $9.5 \$ \mathrm{AUD} / \mathrm{m}^{2}$ depending on the type of concrete, method of construction, and the climate of the city.

The operational phase shows that $\mathrm{CO}_{2}$-e emission due to energy consumption is strongly influenced by the weight of construction and type of concrete (Normal Weight and Ultra-lightweight) used in the building. In general, a Lightweight building with Normal density concrete (Waffle.Normal) uses less energy than the alternatives, and therefore produces less $\mathrm{CO}_{2}$-e during the operating phase. In contrast, the Lightweight structures designed with Ultra-lightweight concrete had higher lifetime $\mathrm{CO}_{2}$-e emissions and environmental costs (up to 5.5\%) than the other design alternatives.

The results of the study have shown that the Waffle slab with a right type of concrete (Normal Weight) can save up to $\$ 156$ per $\mathrm{m}^{2}$ (average value across all cities) in the total life cycle cost of the building across all five cities.

The findings of this study show that selecting the optimal structural design based on a specific stage of building's life cycle could make it difficult to choose the ideal design alternatives. This is why all the stages of life cycle assessment must be 
considered when selecting alternative designs to achieve more environmentally friendly buildings.

The proposed framework provides a method to look beyond the structural system by considering not only the life cycle cost but also the life cycle $\mathrm{CO}_{2}$-e emissions impact that the design alternatives have over the lifetime of buildings.

The findings of this study might also be used as a guideline to optimise the performance of concrete structures by considering the efficiency of the structural materials and construction systems, but further studies must consider the potential impact of other structural forms (timber, steel and Post tensioned) on the whole life cycle of buildings. 


\section{APPENDIX A: WHOLE LIFETIME $\mathrm{CO}_{2}$-e EMISSION ASSOCIATED WITH THE ANALYSIED BUILDINGS}

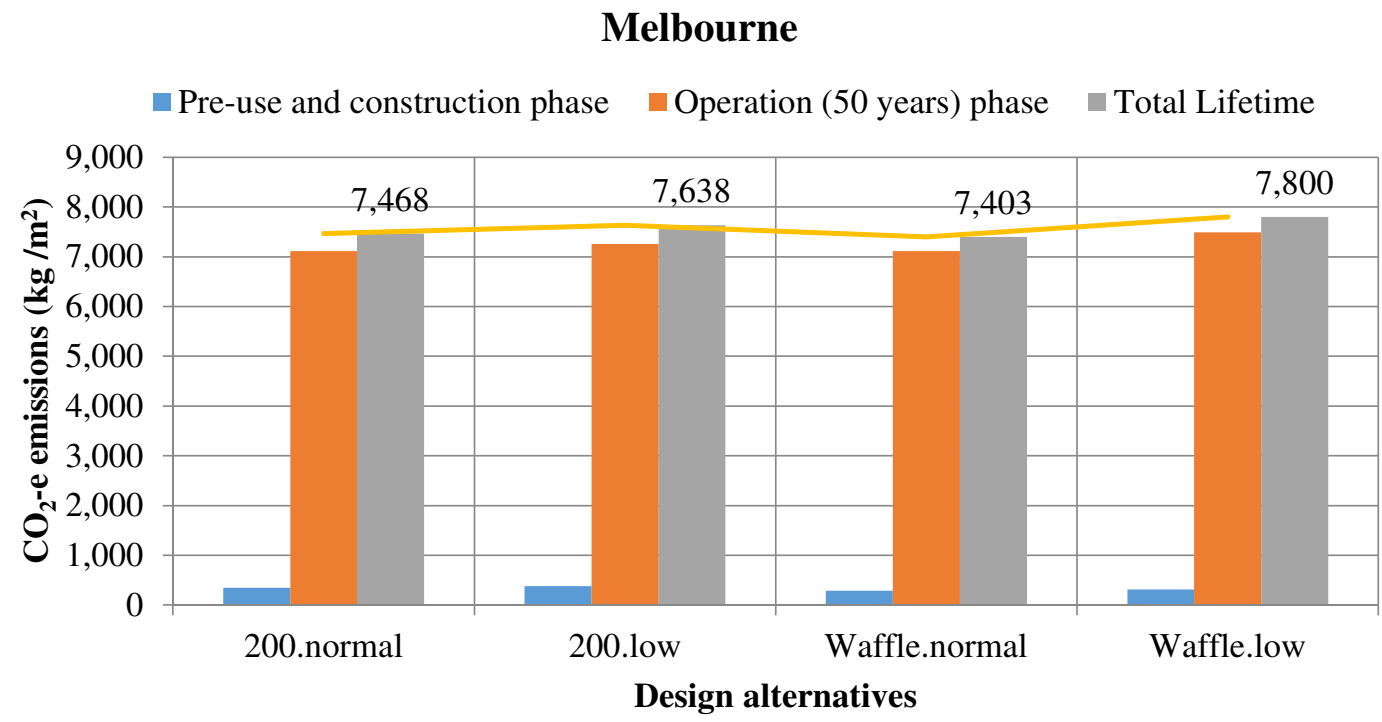

* Victoria average state $\mathrm{CO}_{2}$-e emissions $\left(\mathrm{kg} / \mathrm{m}^{2}\right)$ intensity: 15,872 (BZE 2013; Pitt\&Sherry 2012)

Figure A-1 Life cycle $\mathrm{CO}_{2}$-e emissions normalised by gross floor area and separated by type of concrete and construction method- Melbourne

\section{Canbera}

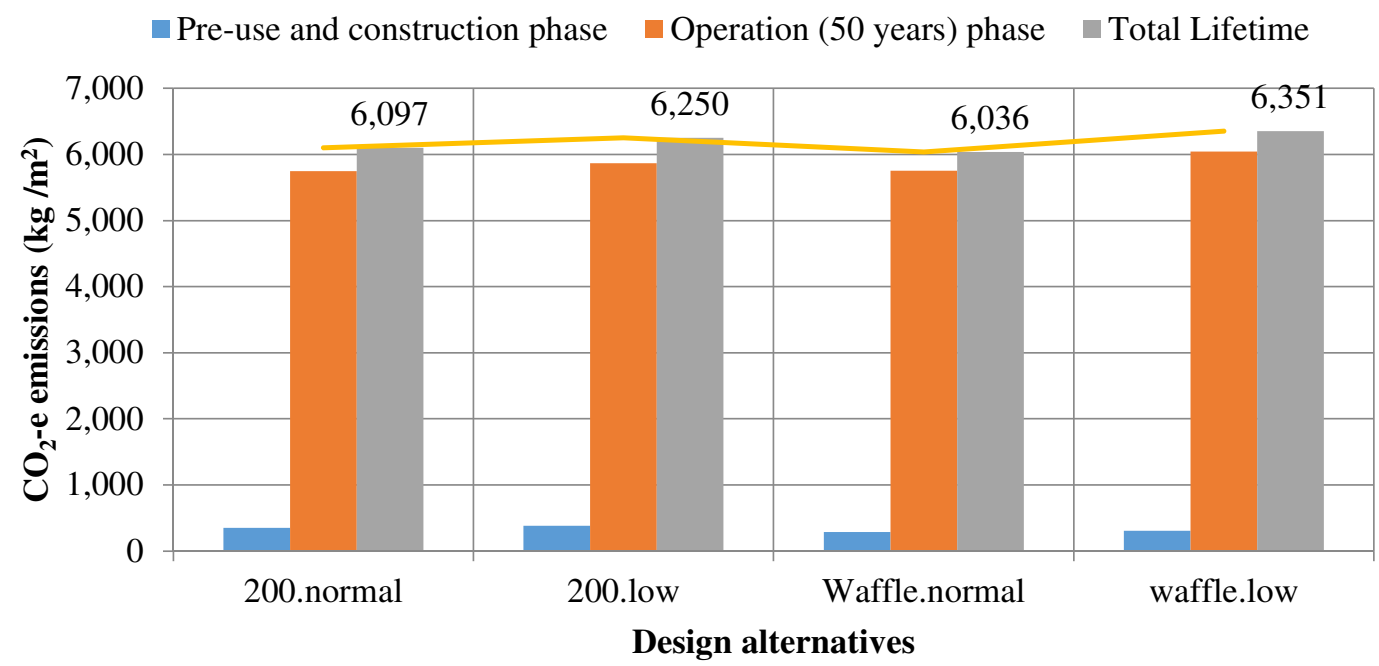

* ACT average state $\mathrm{CO}_{2}$-e emission $\left(\mathrm{kg} / \mathrm{m}^{2}\right)$ intensity: 12,140 (BZE 2013; Pitt\&Sherry 2012)

Figure A-2 Life cycle $\mathrm{CO}_{2}$-e emissions normalised by gross floor area and separated by type of concrete and construction method- Canberra 


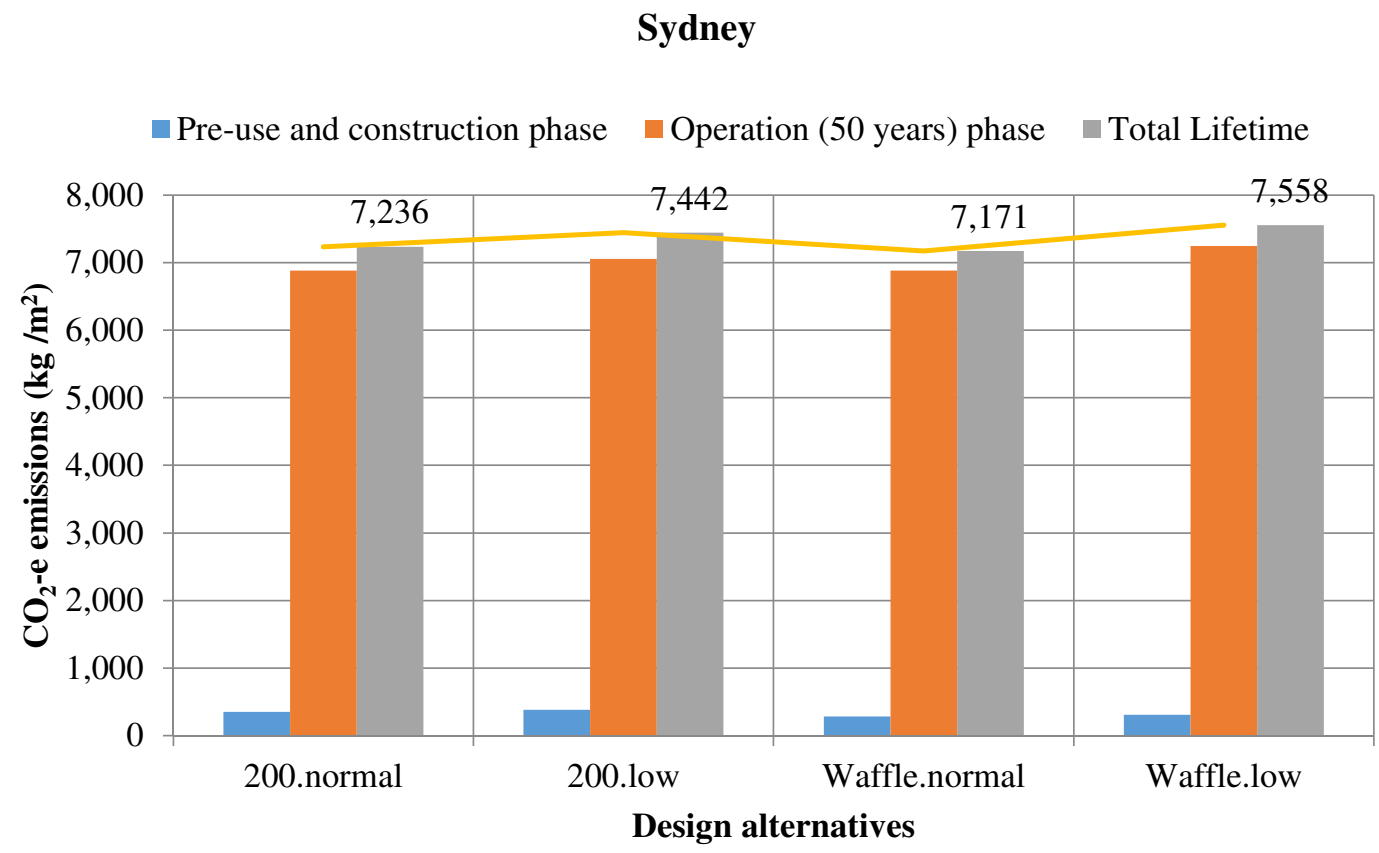

* NSW average state $\mathrm{CO}_{2}$-e emissions $\left(\mathrm{kg} / \mathrm{m}^{2}\right)$ intensity: 12,113 (BZE 2013; Pitt\&Sherry 2012)

Figure A-3 Life cycle $\mathrm{CO}_{2}$-e emissions normalised by gross floor area and separated by type of concrete and construction method- Sydney

\section{Brisbane}

$\square$ Pre-use and construction phase $\quad$ Operation (50 years) phase $\square$ Total Lifetime

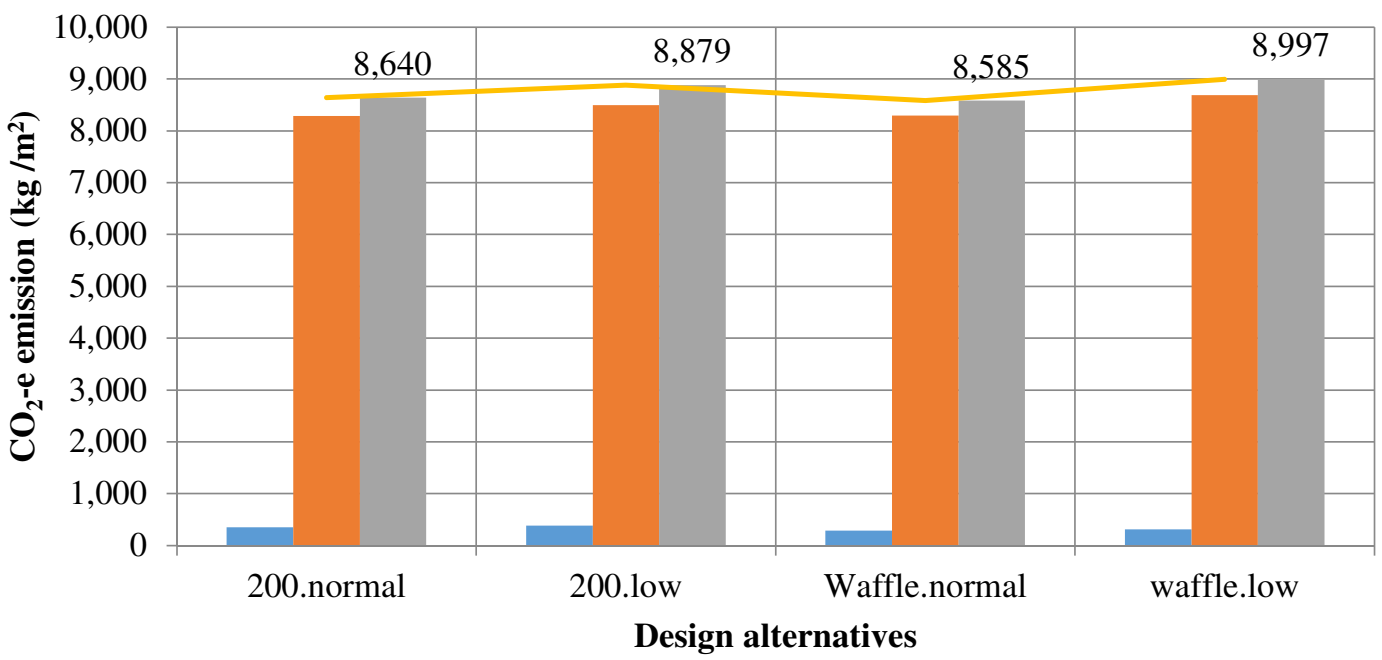

* QLD average state $\mathrm{CO}_{2}$-e emission $\left(\mathrm{kg} / \mathrm{m}^{2}\right)$ intensity: 12,310 (BZE 2013; Pitt\&Sherry 2012)

Figure A-4 Life cycle $\mathrm{CO}_{2}$-e emissions normalised by gross floor area and separated by type of concrete and construction method- Brisbane 


\section{Darwin}

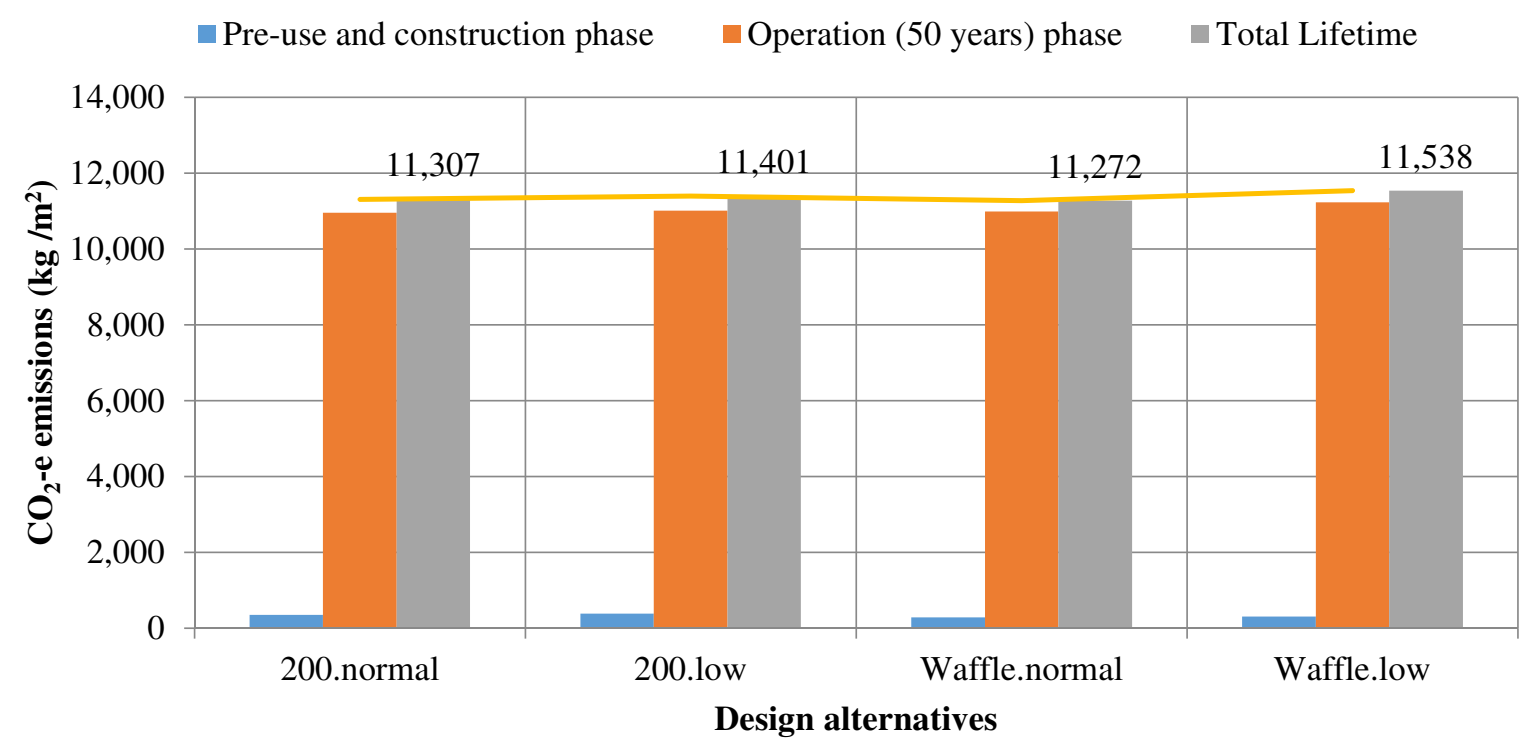

* NT average state $\mathrm{CO}_{2}$-e emission $\left(\mathrm{kg} / \mathrm{m}^{2}\right)$ intensity: 9,421 (BZE 2013; Pitt\&Sherry 2012)

Figure A-5 Life cycle $\mathrm{CO}_{2}$-e emissions normalised by gross floor area and separated by type of concrete and construction method- Darwin 
APPENDIX B: DETAILED STRUCTURAL DESIGN

Table B-1 A summary of Flat slab detailed structural design

\begin{tabular}{|c|c|c|c|c|c|c|c|c|c|c|c|}
\hline \multicolumn{12}{|c|}{ Structure details- Flat slab } \\
\hline \multicolumn{3}{|c|}{ Structure elements } & $\begin{array}{l}\text { Size of } \\
\text { element } \\
\text { (Cross }\end{array}$ & 8 & 足 & $\stackrel{2}{\stackrel{Z}{G}}$ & $\begin{array}{l}\stackrel{0}{0} \\
\stackrel{0}{0} \\
\stackrel{0}{0} \\
\frac{0}{0}\end{array}$ & $\begin{array}{l}\oint \\
\stackrel{0}{0} \\
\frac{0}{0} \\
\frac{0}{0}\end{array}$ & 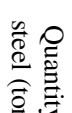 & $\frac{d}{20}$ & $\widehat{\widehat{0}} \stackrel{\overrightarrow{0}}{\stackrel{0}{\Xi}}$ \\
\hline \multirow{10}{*}{$\stackrel{\varrho}{\Xi}$} & \multirow{2}{*}{$\begin{array}{l}\text { Level } 1 \\
\text { to } 3\end{array}$} & Interior & $500 \times 500$ & \multirow{10}{*}{$\mathrm{N} 40$} & $10 \mathrm{~N} 32$ & 24 & 20 & \multirow{10}{*}{93} & 18 & $3 \%$ & \multirow{10}{*}{83} \\
\hline & & perimeter & $350 \times 350$ & & $8 \mathrm{~N} 28$ & 24 & 10 & & 11 & $4 \%$ & \\
\hline & \multirow{2}{*}{$\begin{array}{l}\text { Level } 4 \\
\text { to } 6\end{array}$} & Interior & $400 \times 400$ & & $10 \mathrm{~N} 28$ & 24 & 13 & & 13 & $4 \%$ & \\
\hline & & perimeter & $325 \times 325$ & & $8 \mathrm{~N} 24$ & 24 & 8 & & 8 & $3 \%$ & \\
\hline & \multirow{2}{*}{$\begin{array}{l}\text { Level } 7 \\
\text { to } 9 \\
\end{array}$} & Interior & $375 \times 375$ & & $10 \mathrm{~N} 20$ & 24 & 11 & & 7 & $2 \%$ & \\
\hline & & perimeter & $300 \times 300$ & & $8 \mathrm{~N} 20$ & 24 & 7 & & 6 & $3 \%$ & \\
\hline & \multirow{2}{*}{$\begin{array}{c}\text { Level } \\
10 \text { to } 12\end{array}$} & Interior & $375 \times 375$ & & $8 \mathrm{~N} 24$ & 24 & 8 & & 8 & $3 \%$ & \\
\hline & & perimeter & $300 \times 300$ & & $8 \mathrm{~N} 20$ & 24 & 5 & & 6 & $3 \%$ & \\
\hline & \multirow{2}{*}{$\begin{array}{c}\text { Level } \\
13 \text { to } 15 \\
\end{array}$} & Interior & $275 \times 275$ & & $6 \mathrm{~N} 16$ & 24 & 6 & & 2 & $3 \%$ & \\
\hline & & perimeter & $250 \times 250$ & & & 24 & 5 & & 4 & $3 \%$ & \\
\hline$\frac{\tilde{n}}{\ddot{\sigma}}$ & \multicolumn{2}{|c|}{$\begin{array}{l}\text { Suspended floor with } \\
\text { drop panel }\end{array}$} & $\begin{array}{c}200 \mathrm{~mm} \\
\text { (depth) }\end{array}$ & N32 & \multicolumn{2}{|c|}{$\begin{array}{l}\text { Bot- N12@100 } \\
\text { mm (Same for } \\
\text { both directions)+ } \\
\text { Drop panel } \\
\text { (N12@300 mm) }\end{array}$} & 2469 & 3,000 & 654 & $0.56 \%$ & 654 \\
\hline & \multicolumn{2}{|c|}{ Wall } & $\begin{array}{c}200 \mathrm{~mm} \\
\text { (thickness) }\end{array}$ & $\mathrm{N} 40$ & \multicolumn{2}{|c|}{$\begin{array}{c}\text { N12@300 mm } \\
\text { both sides (Top \& } \\
\text { Bottom) }\end{array}$} & --- & 31 & 9 & $4 \%$ & 9 \\
\hline & \multicolumn{2}{|c|}{ Staircase } & $\begin{array}{c}15 \mathrm{~mm} \\
\text { (thickness) }\end{array}$ & $\mathrm{N} 20$ & \multicolumn{2}{|c|}{$\begin{array}{l}\text { N12@200 mm } \\
\text { both directions }\end{array}$} & --- & 250 & 7 & $1 \%$ & 7 \\
\hline
\end{tabular}

Table B-2 A summary of Waffle slab detailed structural design.

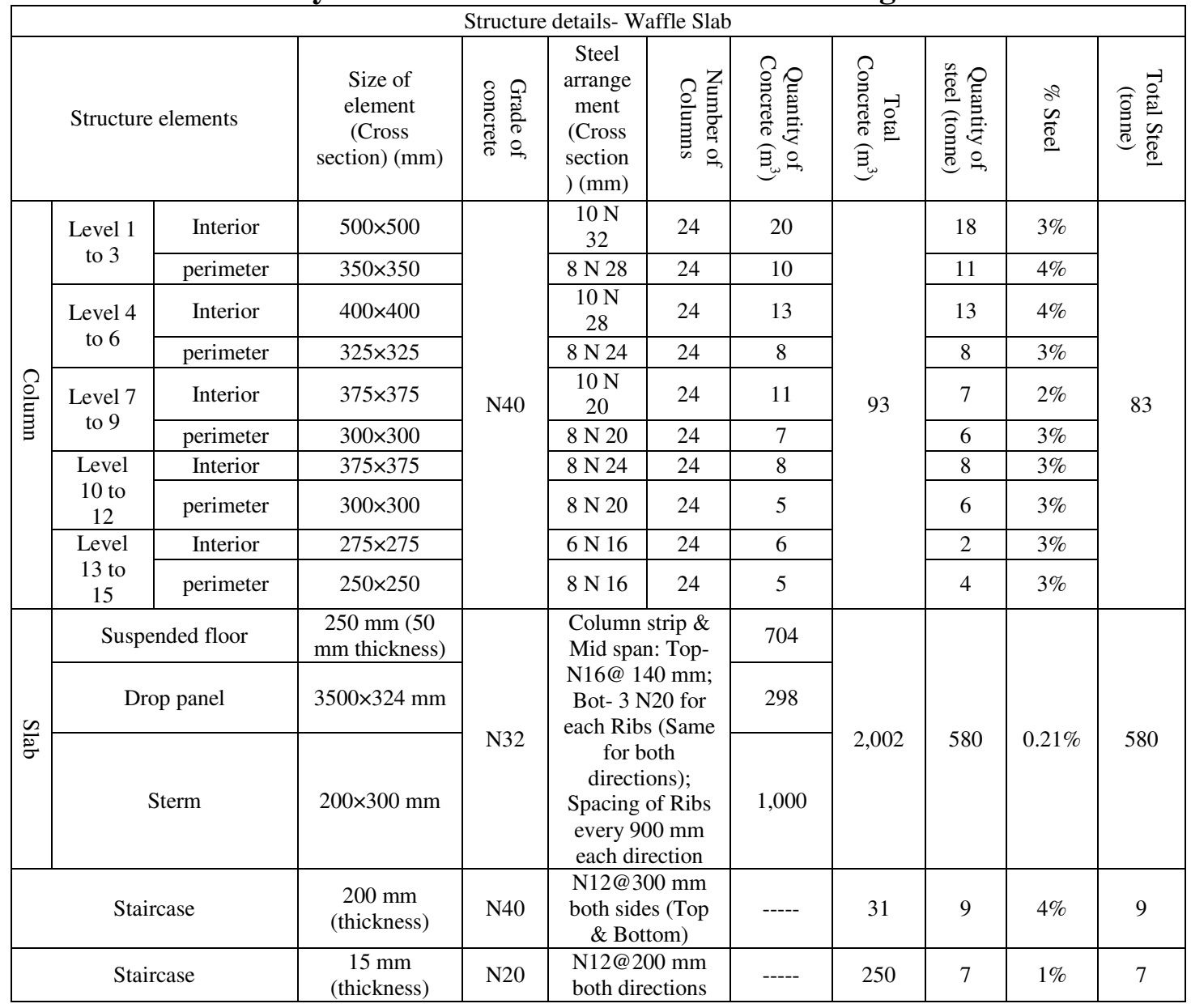




\section{References}

ABCB 2015, National construction code, volume one Australian Building Codes Board, Canberra.

ABCB 2016, Energy efficiency provisions, National counstruction code volume two, Australian Building Codes Board, Canberra.

Adams, PD, Parmenter, BR \& Verikios, G 2014, 'An emissions trading scheme for Australia: national and regional impacts', Economic Record, vol. 90, no. 290, pp. 316-44.

Akbarnezhad, A \& Xiao, J 2017, 'Estimation and Minimization of Embodied Carbon of Buildings: A Review', Buildings, vol. 7, no. 1, p. 5.

Alcorn, A 2003, Embodied energy and CO2 coefficients for NZ building materials, Centre for Building Performance Research, Wellington, New Zealand.

Appleby, P 2012, Integrated sustainable design of buildings, Routledge.

AS3600 2009, Concrete structures, Standards Australia International Ltd, Sydney, Australia.

AS/NZ1170.0 2002, Part0: General principles structure design actions, Standards Australia International Ltd, Sydney, Australia.

AS/NZ1170.1 2002, Part 1: Permanent, imposed and other actions, Australian/ New Zealand Standard, Standards Australia International Ltd.

AS/NZ1170.2 2011, Part 2: Wind actions, Standards Australia International Ltd, Sydney, Australia.

AS/NZ4536 2014, Life cycle costing-An application guide, Standards Australia International Ltd, Sydney, Australia., Sydney, Australia.

AusLCI 2016, The Australian national life cycle inventory database, http://alcas.asn.au/.

Aye, L, Ngo, T, Crawford, RH, Gammampila, R \& Mendis, P 2012, 'Life cycle greenhouse gas emissions and energy analysis of prefabricated reusable building modules', Energy and Buildings, vol. 47, pp. 159-68.

Bekas, GK, Kaziolas, DN \& Stavroulakis, GE 2015, 'Life Cycle Analysis and Optimization of a Steel Building', in ND Lagaros \& M Papadrakakis (eds), Engineering and Applied Sciences Optimization: Dedicated to the Memory of Professor M.G. Karlaftis, Springer International Publishing, Cham, pp. 38598.

Boral 2017, Building and construction materials, viewed 25/2/2017, $<$ http://www.boral.com.au/>.

BZE 2013, Zero carbon Australia buildings plan, Beyond Zero Emissions, Melbourne Energy Institute, University of Melbourne, Melbourne, Australia.

Cabeza, LF, Barreneche, C, Miró, L, Morera, JM, Bartolí, E \& Inés Fernández, A 2013, 'Low carbon and low embodied energy materials in buildings: A review', Renewable and Sustainable Energy Reviews, vol. 23, pp. 536-42.

CCAA 2015, 'Green Star Mat-4 Concreet Credit User Guide', Cement Concrete \& Aggregates Australia.

Cha, K, Lim, S \& Hur, T 2008, 'Eco-efficiency approach for global warming in the context of Kyoto Mechanism', Ecological Economics, vol. 67, no. 2, pp. 27480.

Chou, J-S \& Yeh, K-C 2015, 'Life cycle carbon dioxide emissions simulation and environmental cost analysis for building construction', Journal of Cleaner Production, vol. 101, pp. 137-47. 
Combet, G 2012, Securing a clean energy future : implementing the Australian Government's climate change plan, The Australian Government Department of Climate Change and Energy Efficiency, Canberra, Australia, ISBN 978-1922003-44-7.

Cordell 2016, Building cost guide : Commercial industrial - NSW, Cordell Building Publications, Australia.

Crawford, R 2011, Life cycle assessment in the built environment, Taylor \& Francis.

Daly, D, Cooper, P \& Ma, Z 2014, 'Implications of global warming for commercial building retrofitting in Australian cities', Building and Environment, vol. 74, pp. 86-95.

DEE 2015, Australia's 2030 emissions reduction target, Department of Environment and Energy, Canberra, Australia, http://www.environment.gov.au.

DEE 2016, Australia's emissions projections 2016, Department of the Environment and Energy, Canberra, Australia, http://www.environment.gov.au.

DEE 2016, National greenhouse accounts factors, Department of the Environment and Energy, Canberra, Australia, http://www.environment.gov.au.

DIIS 2013, Your home : Australia's guide to environmentally sustainable homes, Department of Industry, Innovation and Science, Canberra, Australia.

Duxson, P \& Provis, JL 2008, 'Low CO2 concrete: are we making any progress', Environment design guide, Australian Institute of Architects.

Eastchem 2017, Chemical products manufacturers, viewed 25/2/2017, $<\mathrm{http}: / /$ www.eastchem.cn $>$.

Economics, F 2015, Electricity market forecasts: 2015, Frontier Economics, Sydney, http://www.frontier-economics.com.

Egan, A 2011, 'AIR TIGHTNESS OF AUSTRALIAN OFFICES BUILDINGS: REALITY VERSUS TYPICAL ASSUMPTIONS USED IN ENERGY PERFORMANCE SIMULATION', Building Simulation, International Building Performance Simulation Association, Sydney.

eTool 2014, Life cycle assessment online tool, viewed 23/6/2015, $<$ http://etoolglobal.com/>.

Ferreiro-Cabello, J, Fraile-Garcia, E, Martinez de Pison Ascacibar, E \& Martinez de Pison Ascacibar, FJ 2016, 'Minimizing greenhouse gas emissions and costs for structures with flat slabs', Journal of Cleaner Production, vol. 137, pp. 922-30.

Flores, C 2015, How Australian buildings have achieved unprecedented energy savings, The National Australian Built Environment Rating System (NABERS),

https://www.iea.org/media/workshops/2015/eeuevents/behave1103/S3flores.p df.

Fraile-Garcia, E, Ferreiro-Cabello, J, Martinez-Camara, E \& Jimenez-Macias, E 2015, 'Adaptation of methodology to select structural alternatives of one-way slab in residential building to the guidelines of the European Committee for Standardization (CEN/TC 350)', Environmental Impact Assessment Review, vol. 55, pp. 144-55.

Fraile-Garcia, E, Ferreiro-Cabello, J, Martinez-Camara, E \& Jimenez-Macias, E 2016, 'Optimization based on life cycle analysis for reinforced concrete structures with one-way slabs', Engineering Structures, vol. 109, pp. 126-38.

Fraile-Garcia, E, Ferreiro-Cabello, J, Martinez-Camara, E \& Jimenez-Macias, E 2017, 'Repercussion the use phase in the life cycle assessment of structures in 
residential buildings using one-way slabs', Journal of Cleaner Production, vol. 143, pp. 191-9.

Glavind, M 2012, Guidelines for green concrete structures: Guide to good practice, Germany, 9782883941076 , https://books.google.com.au/books?id=iOrkAwAAQBAJ.

Gu, L, Lin, B, Zhu, Y, Gu, D, Huang, M \& Gai, J 2008, 'Integrated assessment method for building life cycle environmental and economic performance', in Building Simulation, vol. 1, pp. 169-77.

Guan, L 2009, 'Implication of global warming on air-conditioned office buildings in Australia', Building Research \& Information, vol. 37, no. 1, pp. 43-54.

Hahn, T, Figge, F, Liesen, A \& Barkemeyer, R 2010, 'Opportunity cost based analysis of corporate eco-efficiency: A methodology and its application to the CO2-efficiency of German companies', Journal of Environmental Management, vol. 91, no. 10, pp. 1997-2007.

Hajdukiewicz, M, Byrne, D, Keane, MM \& Goggins, J 2015, 'Real-time monitoring framework to investigate the environmental and structural performance of buildings', Building and Environment, vol. 86, pp. 1-16.

Hammond, G, Jones, C, Lowrie, F \& Tse, P 2011, Embodied carbon: the inventory of carbon and energy (ICE), BSRIA.

Hong, T, Ji, C \& Park, H 2012, 'Integrated model for assessing the cost and CO2 emission (IMACC) for sustainable structural design in ready-mix concrete', $J$ Environ Manage, vol. 103, pp. 1-8.

Hong, T, Koo, C \& Kwak, T 2013, 'Framework for the implementation of a new renewable energy system in an educational facility', Applied Energy, vol. 103, pp. 539-51.

Huiskes, DMA, Keulen, A, Yu, QL \& Brouwers, HJH 2016, 'Design and performance evaluation of ultra-lightweight geopolymer concrete', Materials \& Design, vol. 89, pp. 516-26.

IPCC 2014, Climate Change 2014-Impacts, Adaptation and Vulnerability: Regional Aspects, Cambridge University Press, Intergovernmental Panel on Climate Change.

Itsubo, N \& Inaba, A 2003, 'A new LCIA method: LIME has been completed', The International Journal of Life Cycle Assessment, vol. 8, no. 5, p. 305.

Jacobs 2016, Retail electricity price history and projections - Public, Jacobs Australia Pty Limited, Melbourne, Australia.

Ji, C, Hong, T \& Park, HS 2014, 'Comparative analysis of decision-making methods for integrating cost and $\mathrm{CO} 2$ emission - focus on building structural design ', Energy and Buildings, vol. 72, pp. 186-94.

Kaziolas, DN, Bekas, GK, Zygomalas, I \& Stavroulakis, GE 2015, 'Life Cycle Analysis and Optimization of a Timber Building', Energy Procedia, vol. 83, pp. 41-9.

Kim, J, Hong, T \& Koo, C-W 2012, 'Economic and environmental evaluation model for selecting the optimum design of green roof systems in elementary schools', Environmental science \& technology, vol. 46, no. 15, pp. 8475-83.

Lawania, KK \& Biswas, WK 2016, 'Cost-effective GHG mitigation strategies for Western Australia's housing sector: a life cycle management approach', Clean Technologies and Environmental Policy, vol. 18, no. 8, pp. 2419-28.

Moussavi Nadoushani, ZS \& Akbarnezhad, A 2015, 'Effects of structural system on the life cycle carbon footprint of buildings', Energy and Buildings, vol. 102, pp. 337-46. 
NHSC 2011, The key findings of 2011, the state of supply report, Australia.

NS11401.1 2014, Labelling and declaration of environmental attributes of building products- Type III environmental declarations, National Standards Development Organisation Limited, Australia.

O'Moore, LM \& O'Brien, KR 2009, 'Impact of supplementary cementitious material content and transportation distance on greenhouse gas emissions embodied in concrete', in 24th Biennial Conference of Concrete Institute of Australia (Concrete 09), pp. 1-9.

Pitt\&Sherry 2012, Baseline energy consumption and greenhouse gas emissions In commercial buildings in Australia, Council of Australian Governments (COAG) National Strategy on Energy Efficiency.

Poinssot, C, Bourg, S, Ouvrier, N, Combernoux, N, Rostaing, C, Vargas-Gonzalez, M \& Bruno, J 2014, 'Assessment of the environmental footprint of nuclear energy systems. Comparison between closed and open fuel cycles', Energy, vol. 69, pp. 199-211.

Rauf, A \& Crawford, RH 2012, 'The effect of material service life on the life cycle energy of residential buildings', in ASA2012: The 46th Annual Conference of the Architectural Science Association (formerly ANZAScA)-Building on Knowledge: Theory and Practice.

Rawlinsons 2016, Rawlinsons construction cost guide 2016.

RBA 2016, Reserve Bank of Australia-Inflation target., viewed 20/20/2017, $<$ http://www.rba.gov.au/monetary-policy/inflation-target.html>.

Robati, M, Kokogiannakis, G \& McCarthy, TJ 2017, 'Impact of structural design solutions on the energy and thermal performance of an Australian office building', Building and Environment, vol. 124, pp. 258-82.

Robati, M, McCarthy, TJ \& Kokogiannakis, G 2016, 'Incorporating environmental evaluation and thermal properties of concrete mix designs', Construction and Building Materials, vol. 128, pp. 422-35.

Robati, M, McCarthy, TJ \& Kokogiannakis, G 2017, 'A method of uncertainty analysis for life cycle embodied $\mathrm{CO} 2$-e of building and structural materials in Australia', paper presented to 28th Biennial National Conference of the Concrete Institute of Australia., Adelaide, 22-25 October.

Ruuska, AP \& Häkkinen, TM 2015, 'The significance of various factors for GHG emissions of buildings', International Journal of Sustainable Engineering, vol. 8, no. 4-5, pp. 317-30.

Saling, P, Kicherer, A, Dittrich-Krämer, B, Wittlinger, R, Zombik, W, Schmidt, I, Schrott, W \& Schmidt, S 2002, 'Eco-efficiency analysis by BASF: the method', The International Journal of Life Cycle Assessment, vol. 7, no. 4, pp. 203-18.

Sartori, I \& Hestnes, AG 2007, 'Energy use in the life cycle of conventional and lowenergy buildings: A review article', Energy and Buildings, vol. 39, no. 3, pp. 249-57.

Silvestre, J, De Brito, J \& Pinheiro, MD 2014, 'Environmental impacts and benefits of the end-of-life of building materials-calculation rules, results and contribution to a "cradle to cradle" life cycle', Journal of Cleaner Production, vol. 66, pp. 37-45.

Tian, W 2013, 'A review of sensitivity analysis methods in building energy analysis', Renewable and Sustainable Energy Reviews, vol. 20, pp. 411-9. 
Tian, W \& de Wilde, P 2011, 'Uncertainty and sensitivity analysis of building performance using probabilistic climate projections: A UK case study', Automation in Construction, vol. 20, no. 8, pp. 1096-109.

UNFCCC 2008, Kyoto Protocol Reference Manual on Accounting of Emissions and Assigned Amounts, United Nations Framework Convention on Climate Change, Germany.

Van Deventer, JS, Provis, JL \& Duxson, P 2012, 'Technical and commercial progress in the adoption of geopolymer cement', Minerals Engineering, vol. 29, pp. 89-104.

Wu, Y, Wang, J-Y, Monteiro, PJM \& Zhang, M-H 2015, 'Development of ultralightweight cement composites with low thermal conductivity and high specific strength for energy efficient buildings', Construction and Building Materials, vol. 87, pp. 100-12.

Yu, M, Wiedmann, T, Crawford, R \& Tait, C 2017, 'The Carbon Footprint of Australia's Construction Sector', Procedia Engineering, vol. 180, pp. 211-20.

Yu, R, Spiesz, P \& Brouwers, H 2015, 'Development of an eco-friendly Ultra-High Performance Concrete (UHPC) with efficient cement and mineral admixtures uses', Cement and Concrete Composites, vol. 55, pp. 383-94.

Yun, TS, Jeong, YJ, Han, T-S \& Youm, K-S 2013, 'Evaluation of thermal conductivity for thermally insulated concretes', Energy and Buildings, vol. 61, pp. 125-32.

Zuo, J, Pullen, S, Rameezdeen, R, Bennetts, H, Wang, Y, Mao, G, Zhou, Z, Du, H \& Duan, H 2017, 'Green building evaluation from a life-cycle perspective in Australia: A critical review', Renewable and Sustainable Energy Reviews, vol. 70, pp. 358-68. 